\title{
DEPOCEN
}

Working Paper Series No. 2018/02

\section{VIETNAM SMEs' PARTICIPATION IN REGIONAL ECONOMIC INTEGRATION Survey Results of Three Manufacturing Sectors}

\author{
Nguyen Dinh Chuc ${ }^{2}$ \\ Ngoc Anh Nguyen ${ }^{1}$
}

${ }^{2}$ Center for Sustainable Urban Development

${ }^{1}$ Development and Policies Research Center (DEPOCEN), Hanoi, Vietnam

\begin{abstract}
The DEPOCEN WORKING PAPER SERIES disseminates research findings and promotes scholar exchanges in all branches of economic studies, with a special emphasis on Vietnam. The views and interpretations expressed in the paper are those of the author(s) and do not necessarily represent the views and policies of the DEPOCEN or its Management Board. The DEPOCEN does not guarantee the accuracy of findings, interpretations, and data associated with the paper, and accepts no responsibility whatsoever for any consequences of their use. The author(s) remains the copyright owner.
\end{abstract}

DEPOCEN WORKING PAPERS are available online at http://www.depocenwp.org 


\section{9}

\section{VIETNAM SMEs' PARTICIPATION} IN REGIONAL ECONOMIC INTEGRATION Survey Results of Three Manufacturing Sectors

Nguyen Dinh Chuc, Nguyen Ngoc Anh and Nguyen Thi Kim Thai

\section{Introduction}

During the course of development, small and medium-sized enterprises (SMEs) are seen as the cornerstone of a national economy and significant contributors to the prosperity of a country. SMEs play an important role in a wide spectrum of industries in a country. The number of SMEs dominates that of large and very large enterprises. They contribute significantly to a country's economic growth and employment creation of most countries. Most governments view the SME sector as a key engine of the economy and a source of employment creation (Harvie 2010). 
The role of SMEs, however, was not recognized until the mid-1970s. Before that concentration and centralization of economic activities were seen as the main evidence of a firm's competitiveness and large firms received much attention. SMEs' contributions to economic activity only began to be a priority after the Bolton Report in the UK (1971) and the Wiltshire Report in Australia (1971) on the role of SMEs in the economies of the UK and Australia, respectively were published (Al-Qirim 2004).

In Europe, two-thirds of all new jobs are created by SMEs and more than 99 per cent of all enterprises are SMEs. In the United States, more than 99 per cent of all independent enterprises employ fewer than 500 employees, which is the definition of an SME in the United States. These SMEs employ 52 per cent of all U.S. workers (Devos et al. 2014).

In Australia, SMEs is a substantial sector, making up 95 per cent of all enterprises (Chau and Turner 2004). These enterprises contribute $\$ 530$ billion to the economy in 2010-11, more than half of private sector economic activities, and employed over 7 million people, generating more than two thirds of private sector employment (Deloitte 2013).

In East Asia, SMEs account for about 98 per cent of all enterprises, equivalent to between 20 and 30 million businesses. In the three largest economies of East Asia - Japan, China and Korea - SMEs account for 70 per cent of SMEs in the region (China: 8 million; Japan: 5 million; and Korea: 2.6 million). The intensity ratio of SMEs is only 20 people per SME in developed countries. The regional developing countries have a ratio of about 100 people per SME, making an average of 85 people for every SME in the region. The SMEs sector creates about 60 per cent of the private sector employment and about 30 per cent of the total workforce, but contributes about 70 per cent of net employment growth of the region. Most SMEs in the region are micro enterprises with more than 80 per cent of them with less than 5 employees (Harvie and Lee 2005).

In Vietnam, SMEs accounted for 98 per cent of total enterprises in 2012, increased from 94.6 per cent in 2000. The SMEs sector created jobs for more than 5.4 million workers, 4.6 times higher than the number of jobs created by SMEs in 2000. More importantly, SMEs in Vietnam are cost effective in generating off-farm employment for the economy. ${ }^{1}$

Given the importance of SMEs in the economy and deeper integration into the world economy, the capacity of internationalization of SMEs in particular and competitiveness of domestic enterprise sector in general are important for the development of the country. Internationalization 
of SMEs is seen as a form of development of these enterprises and the domestic economic environment. The internationalization of SMEs, however, is affected by numerous factors, ranging from the size of home market, government policies, firm-specific advantages, and trade barriers (Nordstrom 1991).

With the increasing regional economic integration and the implementation of ASEAN Economic Community (AEC), this study looks into details the current situation of Vietnamese SMEs with regard to the participation into the regional economy. The study aims to identify enabling factors and obstacles to this process of Vietnamese SMEs in three sectors: (i) wooden products manufacturing; (ii) textile and garment; and (iii) food processing. A survey of 208 enterprises in these three sectors was conducted to establish a better understanding of the participation of Vietnamese enterprises in the regional economy.

With the exception of the introduction, this chapter is divided into four parts. The first part examines the current economic environment for the development of SMEs in Vietnam and discusses the Vietnamese SMEs' performance. The second part examines the current situation of the three survey sectors of the economy. The third part discusses results of the survey. The last part concludes the analyses and presents policy recommendations for strengthening integration of Vietnamese SMEs into the regional economy.

\section{SMEs in Vietnam and Government Policies}

\section{SMEs' Definition}

The SME definition varies from country to country in accordance to the development of the economy, characteristics of the sector and government policy. Most dominantly, the definition depends on enterprise sector situation in the countries and usually reflects the relative correlation between capital and labour in these countries. In the United States, an SME is defined as "one which is independently owned and operated and which is not dominant in its field of operation", ${ }^{2}$ which is based on the position of the organization within the overall marketplace. Also, the definition of an SME differs according to sector in the United States, e.g. in the manufacturing sector, an SME has 500 employees or fewer, while in the services industry, an SME is defined in terms of annual receipts (US\$6 million or less) (MacGregor and Vrazalic 2007). 
In Australia, the Australian Bureau of Statistics (ABS) defines a small business as an enterprise employing up to 99 people, a medium one as having between 100 and 199 individuals, and a business with more than 200 employees is considered a large enterprise. In the UK, the UK Companies Act of 1989 declared an SME to be an enterprise having fewer than 50 employees and not a subsidiary of any other company (MacGregor and Vrazalic 2007).

The World Bank has its own definitions. A "micro" enterprise has less than 10 employees with total assets of less than US\$10,000 and total annual sales of less than US\$100,000. An enterprise is considered "small" if it employs fewer than 50 employees and has total assets or total annual sales of less than US\$3 million. The medium enterprise is one with less than 300 employees and total assets or total annual sales of less than US\$15 million.

In Vietnam, SMEs are officially defined by the government for the first time in Decree 90/2001/ND-CP as enterprises with registered capital of under VND 10 billion (about US\$500,000) and fewer than 300 employees. These standards are generally maintained in the new definition on SMEs in Decree 56/2009/ND-CP, in which both labour and capital are used as criteria for defining SMEs. This follows international practice. In terms of labour, the practice is followed strictly, however, in terms of capital, the threshold is much lower (see Table 9.1). It reflects the fact that labour is abundant and the economy needs more capital.

TABLE 9.1

Vietnam's Definition of SMEs

\begin{tabular}{l|c|c|c|c|c}
\hline \multirow{2}{*}{ Sector } & $\begin{array}{c}\text { Micro } \\
\text { Enterprises }\end{array}$ & \multicolumn{2}{|c|}{ Small Enterprises } & \multicolumn{2}{c}{ Medium Enterprises } \\
\cline { 2 - 6 } & Labour & $\begin{array}{c}\text { Total } \\
\text { Capital } \\
\text { (billion } \\
\text { VND) }\end{array}$ & Labour & $\begin{array}{c}\text { Total } \\
\text { Capital } \\
\text { (billion } \\
\text { VND) }\end{array}$ & Labour \\
\hline $\begin{array}{l}\text { Agriculture, forestry, } \\
\text { aquaculture }\end{array}$ & $<=10$ & $<=20$ & $10-200$ & $20-100$ & $200-300$ \\
\hline $\begin{array}{l}\text { Industry and } \\
\text { construction }\end{array}$ & $<=10$ & $<=20$ & $10-200$ & $20-100$ & $200-300$ \\
\hline Trade and services & $<=10$ & $<=10$ & $10-50$ & $10-50$ & $50-100$ \\
\hline
\end{tabular}

Source: Decree 56/2009/ND-CP. 


\section{SMEs in Vietnam}

SMEs dominate the number of enterprises in Vietnam. According to the fourth establishment census ${ }^{3}$ conducted by the General Statistics Office in 2012, there are about 4.9 million economic establishments in Vietnam. They create 18.9 million jobs for the economy. Among the economic establishments, 4.6 million are unregistered and operate as household businesses. It is estimated that 99.9 per cent of the total 4.9 million of economic establishments in the country are micro, small and medium businesses.

In terms of registered enterprises, SMEs accounted for 94.6 per cent of the total 41,964 enterprises in 2000 (see Figure 9.1 and Table 9.2), when the new Enterprise Law was enacted. Since then the establishment of new enterprises has been raising rapidly. The total number of enterprises has increased 7.7 times from 2000 to 2012. During this period, the number of large enterprises has increased 2.2 times and the

FIGURE 9.1

Share of SMEs in Total Number of Enterprises

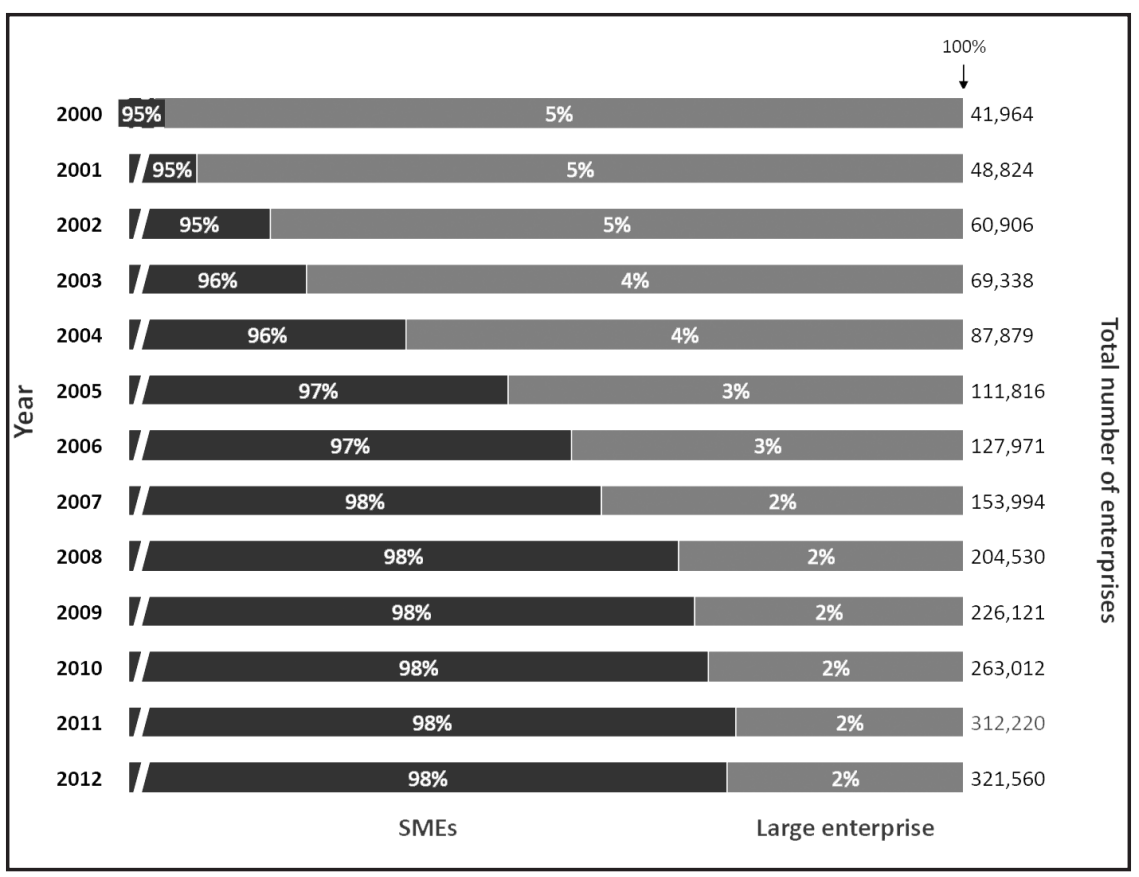

Source: General Statistics Office, Annual Enterprises Census 2001-2013. 


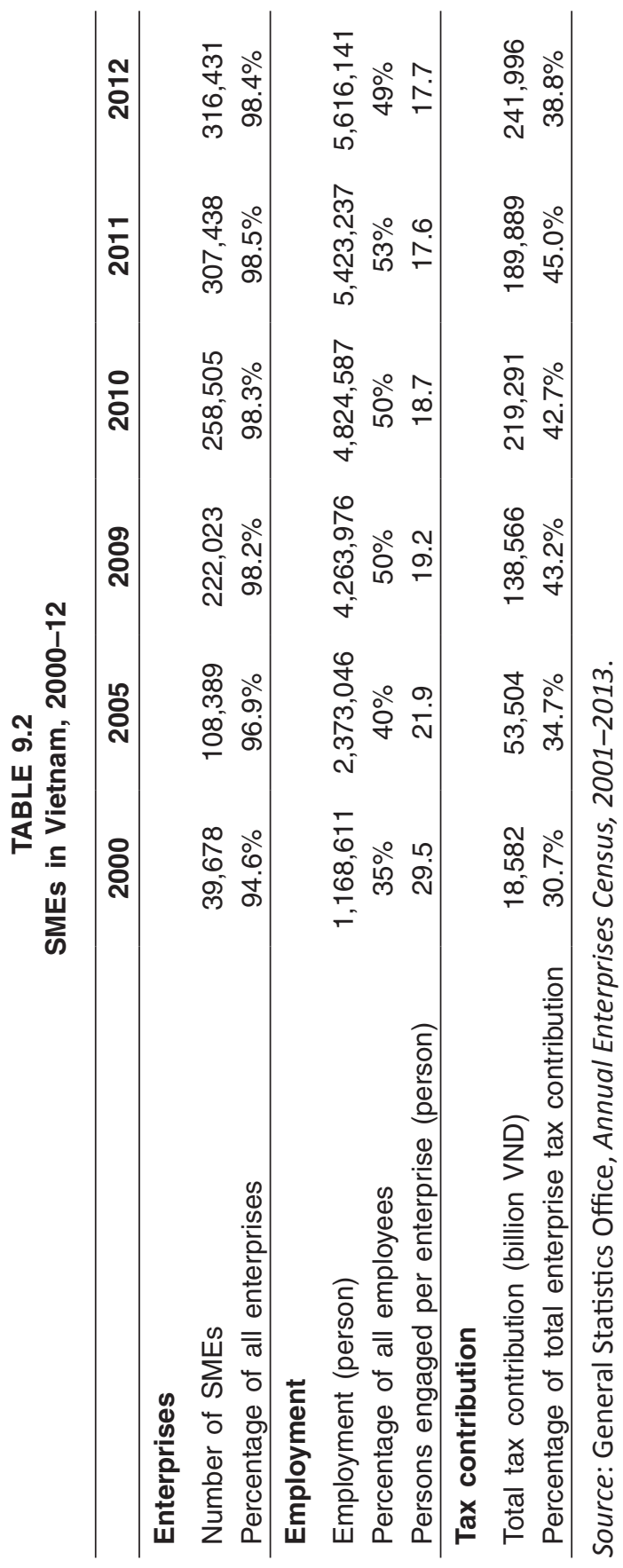


number of SMEs has increased by nearly 8 times. It is clear that most of the newly established enterprises are SMEs. In 2011, they accounted for 98.5 per cent of total enterprises in Vietnam (see Figure 9.1).

The Vietnamese SMEs have similar characteristics with SMEs in other countries. An SME in Vietnam employs an average of 18 persons, which is very close to the average of 20 in Europe. The average size of SMEs in Vietnam has been reducing over the years, from 29.5 labours per enterprise in 2000 to 21.9 labours per enterprise in 2005 and only 17.7 labours per enterprise in 2012. Together SMEs in Vietnam have surpassed large enterprises in terms of jobs creation. Among registered enterprises, the share of employment created by SMEs has increased from 35 per cent of total employment in 2000 to 51 per cent in 2012 (see Figure 9.2).

FIGURE 9.2

Total Employment of Enterprises: SMEs vs. Large Enterprises

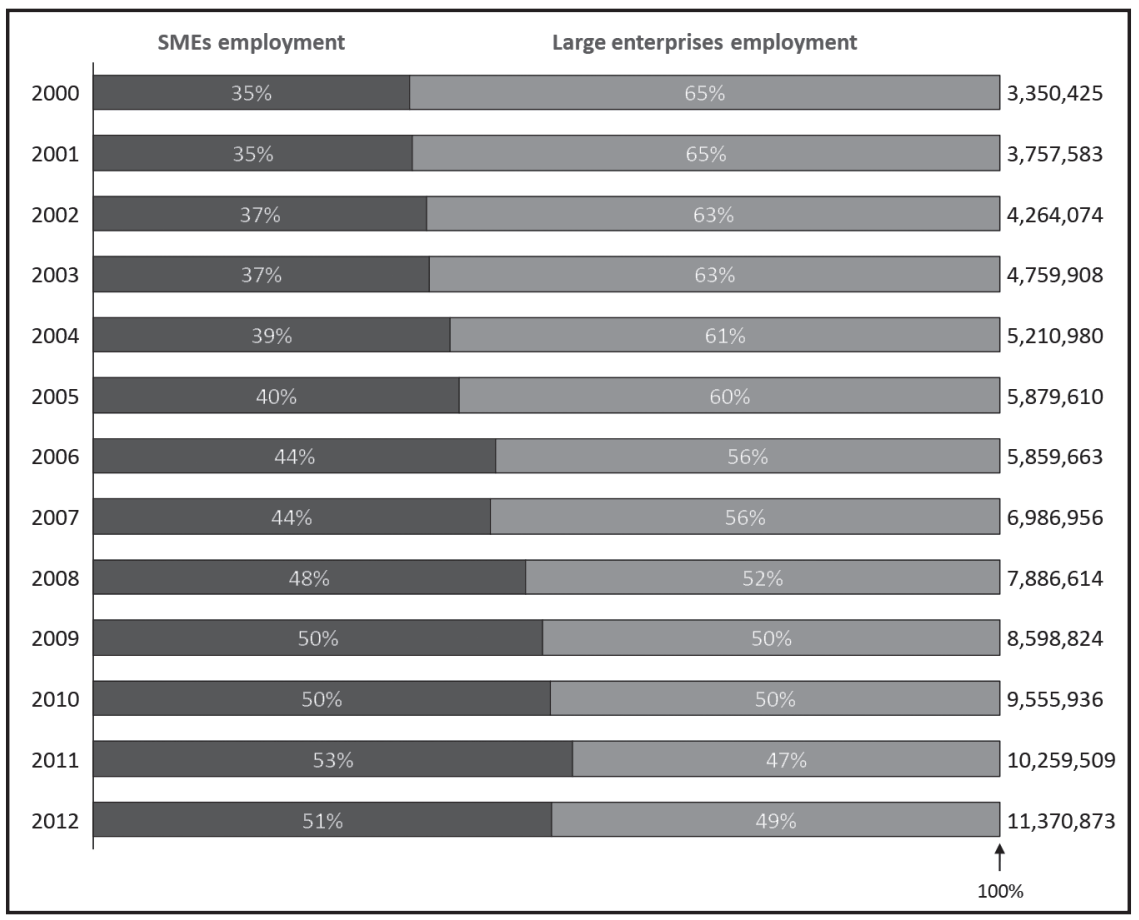

Source: General Statistics Office, Annual Enterprises Census 2001-2013. 
SMEs in Vietnam consist primarily of non-state enterprises. Nonstate SMEs accounted for 97 per cent of total Vietnamese SMEs in 2011. The ratio of SMEs in non-state enterprises has increased from 98.6 per cent in 2000 to 99.2 per cent in 2011. The ratio of SMEs in state-owned enterprises (SOEs) has reduced very slightly from 72.7 per cent in 2000 to 72.2 per cent in 2011. There was a small increase in the ratio of SMEs among foreign-invested enterprises (FIEs), which were 81.4 per cent in 2000 and 83.3 per cent in 2011 (see Table 9.3).

TABLE 9.3

SMEs by Ownership (\%)

\begin{tabular}{l|c|c|c}
\hline & $\mathbf{2 0 0 0}$ & $\mathbf{2 0 0 5}$ & $\mathbf{2 0 1 1}$ \\
\hline State-owned enterprises & 72.7 & 64.9 & 72.2 \\
\hline Non-state enterprises & 98.6 & 98.8 & 99.2 \\
\hline Foreign-invested enterprises (FIEs) & 81.4 & 78.9 & 83.3 \\
\hline
\end{tabular}

In terms of number of enterprises and jobs created, the performance of SMEs has been improving in the past years. Total revenue created by SMEs has increased from 47 per cent in 2000 to 55 per cent in 2011 before reducing to 50 per cent in 2012 (see Figure 9.3). Their share of contribution to stage budget has also increased from 31 per cent in 2000 to 39 per cent in 2012 (see Figure 9.4).

Despite making strong impression on the growth of the number of enterprises as well as the number of jobs created, there are still many difficulties faced by SMEs. Harvie (2007) summarizes impediments to the development of SMEs in Vietnam, including access to land, access to finance, troublesome regulations, access to technology, access to market, access to information, access to skilled human resources, access to information etc. According to the surveys conducted in 2002 and 2005 by the Institute of Labour Science and Social Affairs (ILSSA) in the Ministry of Labour, Invalids and Social Affairs (MOLISA) and University of Copenhagen (Denmark), most important constrains to growth as perceived by entrepreneurs include the shortage of capital and credit, harsh competition in the markets, products not satisfying needs of buyers and lack of access to production sites. 


\section{FIGURE 9.3 \\ Share of SMEs in Total Revenue}

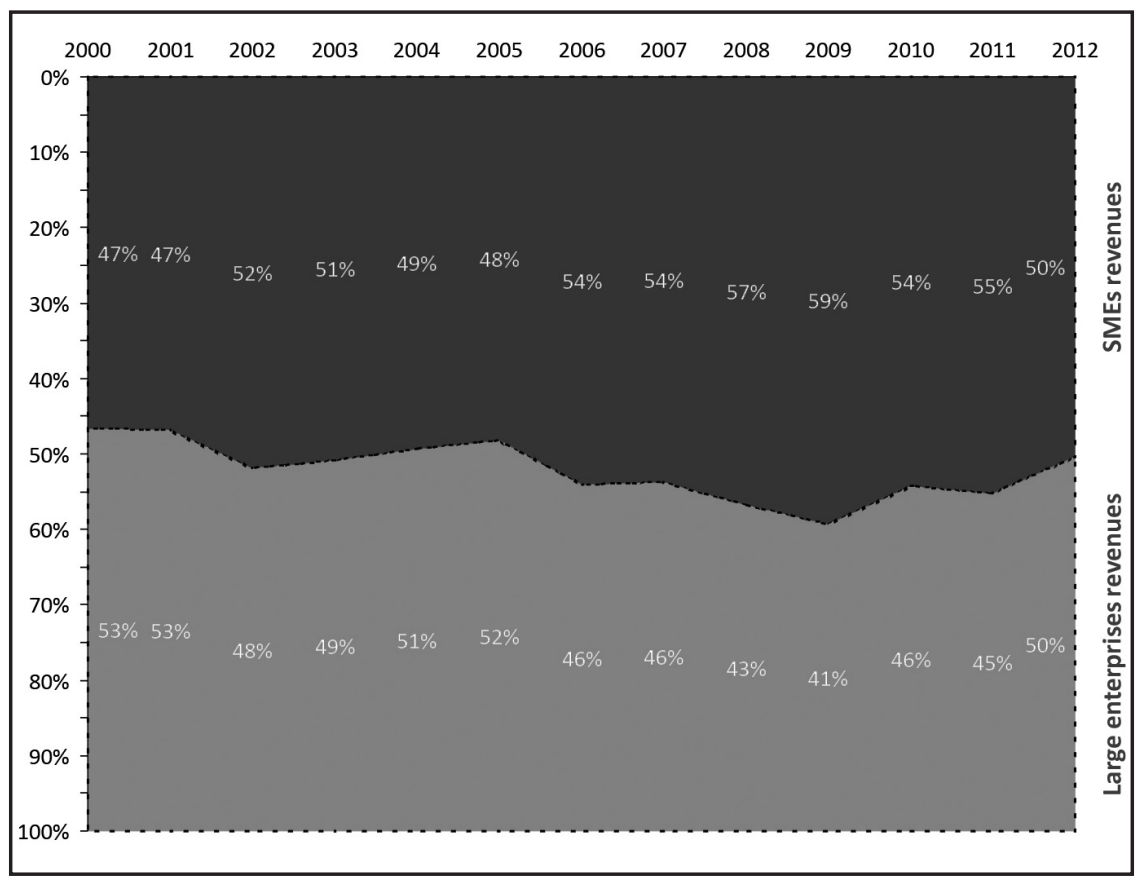

Source: General Statistics Office, Annual Enterprises Census 2001-2013.

Over the past decades, Vietnam has consistently implemented its economic liberalization policy. This results in a more open economy with many bilateral and multilateral trade agreements that have been concluded and implemented. In addition, the existence of FIEs creates huge pressure on domestic enterprises in terms of both mobilizing skilled labour force and competition in domestic market. Over the long term, with the fierce competition in the market and the "creative destruction" process, this will certainly result in a competitive SMEs sector in Vietnam. However, at the moment, SMEs are facing huge difficulties in development.

The development strategy for SMEs drafted by the Ministry of Planning and Investment (MPI) in 2012 pointed out that SMEs have low competitiveness partly due to their outdated technology and equipment. Estimation by MPI shows that the majority of Vietnamese 
FIGURE 9.4

State Budget Contribution: SMEs vs. Large Enterprises

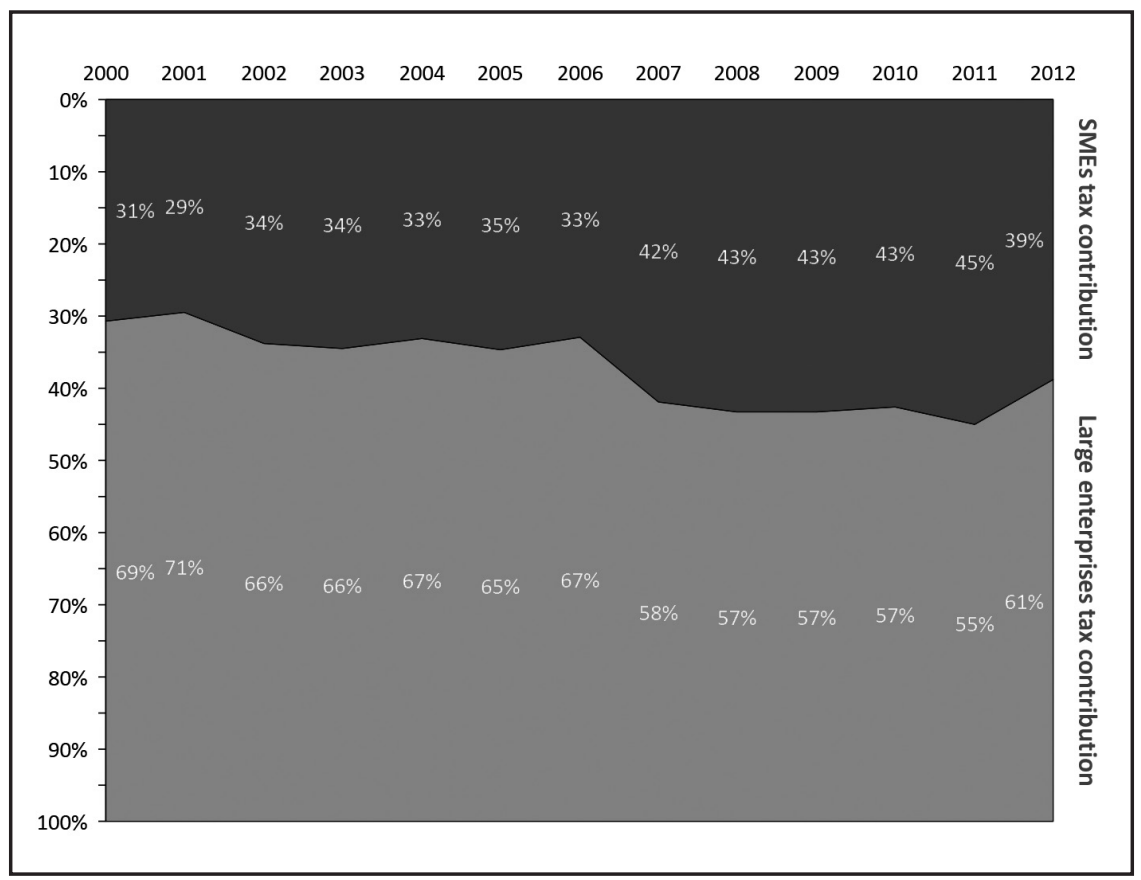

Source: General Statistics Office, Annual Enterprises Census 2001-2013.

enterprises are using technology of three or four generations behind the world's average.

\section{Government Policies to Develop SMEs}

Support for SMEs' development is given attention by the Vietnamese government. The support is given in various aspects, including establishment of enterprises, legal support, capital access, human resource development, market penetration, and technology development. The legal environment for the establishment and operation of SMEs in particular and firms in general has been improved significantly with the revised enterprise law and other related legal documents. Particularly, there are several reforms regarding the establishment and operation of enterprises specified in the Enterprise Law 2014. The law separates the establishment of an enterprise from the establishment 
of an investment project. In which, at the point in time for the establishment of an enterprise, business registration and licence for conditional business sectors are not taken care by the investors. The established enterprises are also proactive in conducting their businesses without concern on business registration as required by the previous enterprise law. In other words, the new enterprise law abandons the requirement for declaration of business sectors by enterprises.

The regulation on stamp of enterprises is also eased to allow enterprises to decide on the form, content, and number of stamps used. Enterprise documents are not required to be stamped, except those requested by their counterparts or by laws. The law redefines SOEs as those with 100 per cent state capital. Other enterprises with state capital of less than 100 per cent will be treated as normal shareholding or limited liability companies. The law also includes new regulations on social enterprises which are differentiated from other enterprises by their use of earned profits. Another reform is that an enterprise can assign their legal representative at their will, instead of a representative specified by law as previously did. These reforms by the revised enterprise law are expected to bring more motivation for the establishment and operation of enterprises in general and SMEs in particular in Vietnam.

In addition, the government has designed a programme to support human resource development for SMEs. The programme is managed by the Agency of Enterprise Development in the Ministry of Planning and Investment to provide start-up enterprises with knowledge and to strengthen governance capacity of entrepreneurs and managers of SMEs. The government supports up to 50 per cent of the total expenditure of training courses. Trainees who live in certain areas will be supported with 100 per cent of accommodation and living costs during the training course (AED 2014).

Internationalization and market penetration of SMEs also receive support from the Ministry of Industry and Trade via the national trade promotion programme. This programme provides various supports to SMEs, including provision of information, consultancy and shortterm training courses, and funds for organizing and participating in international trade fairs and conferences. The government covers up to 100 per cent of total expenditure for such activities. 
Financial access has been provided to SMEs under various programmes, including financing programmes for supporting industries, credit guarantee funds, SMEs development funds, and development credits and export credits of the Vietnam Development Bank (VDB). In addition, production of SMEs is also supported from the cleaner industrial manufacturing fund, industrial production supporting programme, technology market development programme, and national programme for technology innovation to $2020 .{ }^{4}$

In general, the government of Vietnam has realized the importance of SMEs in the economy and has paid attention to design various support programmes for SMEs. These support programmes provide SMEs with legal supports, management and governance knowledge and skills, financial access, trade promotion, market penetration, and technology upgrading. The results, however, are limited. The following analysis aims to get a better understanding of Vietnam SMEs' participation in regional economic integration and the enabling factors and obstacles to SMEs based on the survey conducted on the textile and garment, food and beverage, and wood processing industries.

\section{Current Situation of the Surveyed Industries}

In this research, three manufacturing sectors have been chosen for investigating the participation of Vietnamese SMEs in regional production networks. They are textile and garment, food and beverage, and wood processing industries. These are among the most active industries of Vietnam over the past few years. The following sections describe the three sectors in the economy of Vietnam and government policies towards their development.

\section{Textile and Garment Industry}

In recent years, the textile and garment industry has become one of the major exporting sectors of Vietnam. ${ }^{5}$ Joining the World Trade Organization (WTO) and signing free trade agreements (FTAs) have brought positive impacts on this sector. After becoming a member of WTO, the export turnover of this sector has increased from US $\$ 5.9$ billion in 2006 to US $\$ 15.8$ billion in 2011. In 2011, the textile and garment industry had occupied the leading position on export with a turnover of US $\$ 14.4$ billion, increasing about 9.1 per cent 
(US\$1.2 billion) compared to $2010 .^{6}$ In 2012, the textile and garment sector had reclaimed the first place with an export value of US\$13.2 billion, increasing 17.9 per cent compared with 2011. ${ }^{7}$ In 2013, this sector had been ranked in second place after telephone, mobile phone, and components industry, with a turnover of US\$17.9 billion, increasing 24.4 per cent in comparison with 2012. ${ }^{8}$

Vietnam's textiles and garments have been exported to over 180 countries and territories all over the world, including large and important markets such as the United States, Japan, Korea, Germany, Spain and United Kingdom. Table 9.4 shows the statistics for the top three largest markets — the United States, Japan and Korea.

TABLE 9.4

Export Turnover and Three Major Markets of Vietnam's Textile and Garment Industry, 2011-13

\begin{tabular}{l|c|c|c|c|c|c}
\hline \multirow{2}{*}{$\begin{array}{c}\text { Export Value and } \\
\text { Markets }\end{array}$} & \multicolumn{2}{|c|}{2011} & \multicolumn{2}{c|}{2012} & \multicolumn{2}{c}{2013} \\
\cline { 2 - 7 } & $\begin{array}{c}\text { Export } \\
\text { Value } \\
\text { (billion } \\
\text { USD) }\end{array}$ & $\begin{array}{c}\text { Growth } \\
\text { Rate } \\
\text { (\%) }\end{array}$ & $\begin{array}{c}\text { Export } \\
\text { Value } \\
\text { (billion } \\
\text { USD) }\end{array}$ & $\begin{array}{c}\text { Growth } \\
\text { Rate } \\
\text { (\%) }\end{array}$ & $\begin{array}{c}\text { Export } \\
\text { Value } \\
\text { (billion } \\
\text { USD) }\end{array}$ & $\begin{array}{c}\text { Growth } \\
\text { Rate } \\
\text { (\%) }\end{array}$ \\
\hline Total Export Value & $\mathbf{1 3 . 2}$ & $\mathbf{1 7 . 9}$ & $\mathbf{1 4 . 4}$ & $\mathbf{9 . 1}$ & $\mathbf{1 7 . 9}$ & $\mathbf{2 4 . 4}$ \\
\hline Main markets & & & & & & \\
\hline United States & 6.8 & 10.9 & 7.44 & 8.9 & 8.8 & 17.8 \\
\hline Japan & 1.7 & 52.7 & 1.96 & 17.2 & 2.4 & 21.5 \\
\hline Korea & 0.807 & 98.4 & 1 & 25.4 & 1.6 & 56.3 \\
\hline
\end{tabular}

Source: General Statistics Office, Vietnam's export and import of commodities in 2011, 2012, 2013.

It is expected that with the forthcoming Trans-Pacific Partnership (TPP), FTAs with Korea, the European Union, and the Eurasian Customs Union, the opportunities for the development of Vietnam's textile and garment industry will expand. According to Vietnam Textile and Apparel Association, in 2015, ${ }^{9}$ exports to the U.S., EU and Japanese markets are estimated to grow at 13 per cent, 17 per cent and 9 per cent, respectively. In other words, with the current growth momentum, Vietnam could be in the top ten leading countries in garment and textile by export turnover. 
Vietnam's textile and garment industry has used the advantage of abundant and cheap labour to facilitate the development of the sector Hinh et al. 2013). With deep regional and global economic integration, it is expected that Vietnam's textile and garment enterprises will expand their market to developing countries, in addition to the current markets in developed countries. The industry can compete internationally and satisfy the demand of domestic and international markets, especially in the United States, European Union and Japan and orients toward potential markets in China, New Zealand, India and Russia.

The major obstacles facing the sector are intrinsic barriers including the quality of labour and input costs which outweigh the advantage of low-cost labour in Vietnam (Hinh et al. 2013). Besides, Vietnam textile and garment industry has to face other restrictions and obstacles. One such barrier is the low starting point of the industry, which mainly follows CMT (Cutting-Making-Trimming) production modality that brings less value than FOB (Freight on Board) or $\mathrm{ODM}^{10}$ (Original Design Manufacturer) production modalities. Furthermore, there are a number of obstacles to improving the competitiveness of the sector during the process of integration into the global economy. The main hindrances are that supporting industries have not been developed yet, primary materials have to be imported, the outsourcing ratio is high and competiveness is weaker than other countries in the region. The second barrier is the legal framework with unfinished and lowquality legal documents governing the operation of the industry. The third obstacle is that SMEs in Vietnam have no capacities to defend themselves in anti-dumping lawsuits, resulting in loses in trade disputes when many larger markets have utilized the barriers of technology, sanitary, safety, environment, social responsibility and anti-subsidy to protect domestic producers.

The textile and garment industry has always been a key sector of Vietnam's economy. With the rapid growth and strong development, this sector plays an important role not only in economic growth but also in maintaining trade balance. The government of Vietnam has planned for the industry to be ranked in the top second or third place among the world's textile exporters by 2017-20. Simultaneously, it is expected that Vietnam will have 5-7 per cent leading brands integrating into the global market by $2020 .{ }^{11}$ Besides, textile enterprises also confirmed that Vietnam textile industry is a strong competitor in the international market. ${ }^{12}$ 
Besides implementing common policies, the textile and garment sector also focuses on a number of particular policies to facilitate sector development. In fact, textile and garment enterprises are paying attention on human resource policies. Given the current condition, policies towards the development of the labour force and training high quality workforce to fulfil market demand are preferable. ${ }^{13}$ Furthermore, it is necessary to have better policies for female workers, who are a major workforce in this sector, and to establish gender equality in this industry. ${ }^{14}$

On the other hand, the capital invested in technology has been strengthened and modern equipment and machinery have been installed. However, as analysed above, the textile industry should concentrate on investment projects in order to complete the supply chain (fiber-fabric-dye-clothing manufacture); thus this sector can diversify supply sources, increase localization rates and shift to ODM production modality. If Vietnam's textile and garment industry succeeds in this orientation, it can enhance competiveness as well as close the gap with the textile and garment industry in China.

The extensive integration into regional and global markets leads to Vietnam's textile and garment enterprises attempting to fulfill huge quantities and strict requirements on quality and origin of products. ${ }^{15}$ Besides, it is important to affiliate with enterprises in this sector to boost export and enhance competitiveness. ${ }^{16}$

\section{Food and Beverage Manufacturing}

Food and beverage industry plays an important role and contributes significantly to improving the competitiveness of the economy in integrating into regional and global markets. ${ }^{17}$ The industry includes alcohol-beer-beverages; milk and milk products; vegetable oil; processed food; starch and processed starch; and food industry. So far, the food and beverage industry contributes 15 per cent of GDP and this contribution is still increasing. The revenue of processed food industry outperformed that of the beverage in try. The revenue of beverage industry is expected to increase 7.5 per cent in 2015-16 and this is likely to increase by 10.5 per cent when customers consume higher-value beverages. It is forecasted that along with alcohol, the revenue of beer will increase by 32.8 per cent in 2016. 
According to the Ministry of Industry and Trade, food consumption is expected to grow by 5.1 per cent per year, estimated to be about US\$29.5 billion in 2016. Consumption per capita is estimated to be about VND 5.8 million per year (equivalent to US\$386 per year). In terms of profit, the statistics on the top 1,000 corporate taxpayers in 2013 illustrates that food and beverage industry has the second highest ROE (Return on Equity) and ROA (Return on Total Assets), behind the telecommunications sector. In the list of taxpayers, the food and beverage industry is also ranked in the top five, behind bankingfinance-insurance, telecommunications, minerals and petroleum, and construction and real estate sectors. ${ }^{18}$

FIGURE 9.5

Revenue of the Food and Beverage Industry (billion VND)

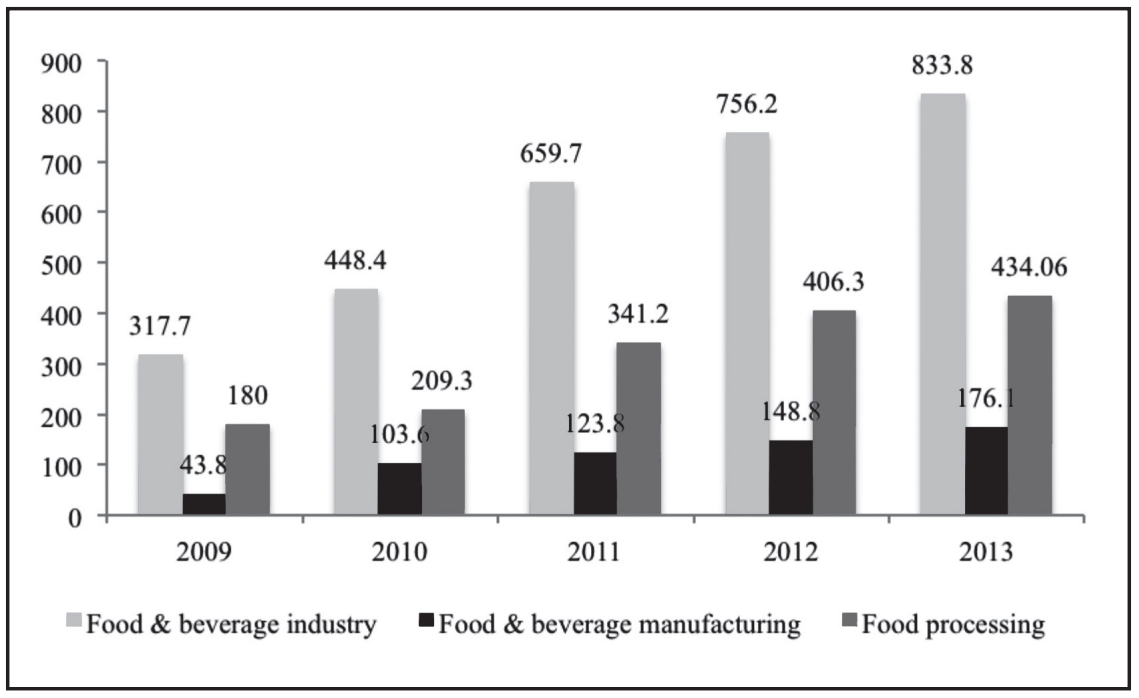

Source: Vietnam Economic Growth Report 2015.

With a population of nearly 90 million people and a high GDP growth rate, Vietnam has huge potential to develop the domestic market as the demand for fresh and processed food is becoming higher and more diversified. Along with that, the government is focusing on developing the agricultural sector, which provides businesses with an 
opportunity to develop their supply chain and linking networks with food service providers.

Vietnam's food and beverage industry has achieved certain results, such as better manufacturing facilities and equipment; using modern technology; making more diversified and high-quality products; greater contribution to the state's budget; and meeting customers' demand better. However, to develop the industry further, the state and enterprises ought to implement better micro and macro policies.

Human resources remains a major barrier, alongside the lack of modern facilities and advanced technology. Therefore, the government and its related ministries should revise and issue new policies to improve management capacity as well as workmanship to operate modern machinery and build advanced facilities. If high-quality manpower for this industry is met, there are chances that the industry can compete in quality and hence goods can be sold at higher prices. ${ }^{19}$

Today, businesses tend to accelerate the process of equitization and are restructuring to improve production efficiency, as well as adjusting to suit market conditions and increasing state management over food safety and hygiene. This is to raise product quality, marking and packaging, comply with requirements and regulations as well as adjust to suit consumers' habit to facilitate penetration into domestic and international markets. There is also the need to review, convert, and supplement the standards of quality, food safety and hygiene in Vietnam to match with international standards. If these measures are well conducted, the competitiveness of the industry can be improved even further.

\section{Wood Processing Industry}

The wood processing industry is one of the economic sectors with impressive growth rates, of which processed products are within the group of highest export turnover in many consecutive recent years. The wood processing and wood products industry is receiving the government's attention in terms of policies, mechanisms to support production, and trade development (Trang and Thuy 2014).

Wood producing and processing entities can be divided into three main groups. These three groups are: (1) wood and non-timber forest products processing enterprises; (2) wood processing facilities in wood villages; and (3) households producing and selling wood furniture. 
Official statistics are only available for the first group (enterprises). The second group is only statistically counted at the wood village level (there are currently 349 wood villages nationwide). The third group is totally not statistically counted.

The number of official wood processing enterprises increased tremendously in recent times. Most wood processing enterprises are small scale (MARD 2013). In terms of the size of the workforce, 46 per cent of woods processing enterprises are micro enterprises, 49 per cent are small enterprises, 1.7 per cent are medium enterprises and 2.5 per cent are large enterprises. In terms of investment, the rate for micro and small scale enterprises is 93 per cent, medium scale enterprises is 5.5 per cent and only 1.2 per cent of the enterprises are large scale. In terms of the source of capital, 5 per cent are SOEs, the remaining 95 per cent are from the private sector. Enterprises with foreign direct investment make up 16 per cent.

As an export-oriented industry, the export capacity of the wood processing industry is a good indicator of its competitiveness. Among 3,400 enterprises in the wood industry, ${ }^{20}$ about 600-700 enterprises (i.e. about 20 per cent of all enterprises) export directly to some Asian, EU and U.S. markets, while the rest either serve as the direct exporter, or focus on the domestic market.

FIGURE 9.6

Vietnam's Wood Product Exporting Markets, 2009 and 2013

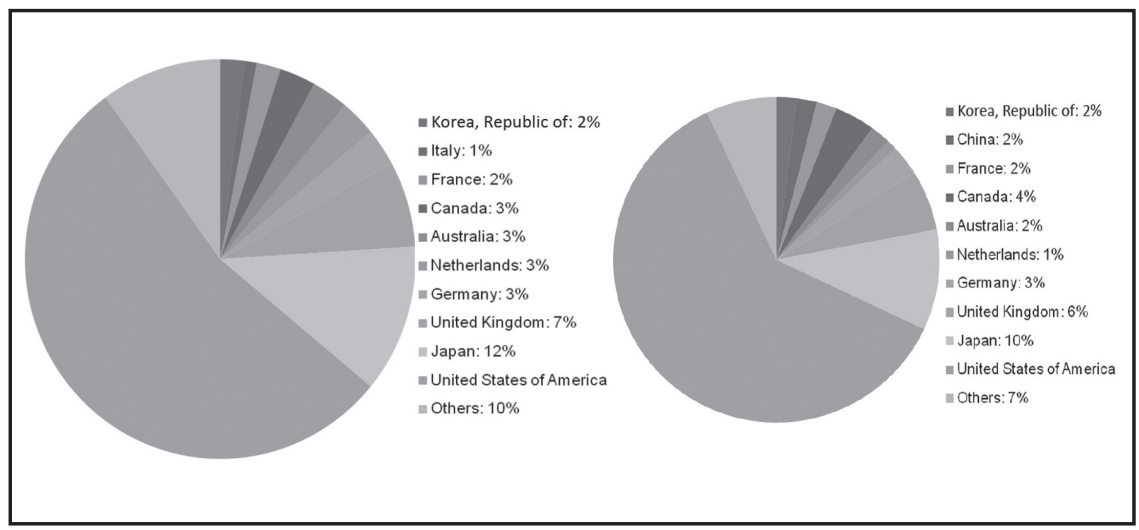

Source: trademap.org. 
Currently, Vietnam's wood export ranks sixth in the ten key export sectors. At the global level, despite the differences between figures from different sources, Vietnam is among the world's largest exporters, ranked second in Asia and first in Southeast Asia. In particular, according to data from the Centre for Industrial Studies (CSIL), Vietnam is the world's sixth largest wood exporter, of which export accounts for above 80 per cent of the total value produced by Vietnam's wood processing industry. Data from the International Trade Centre (ITC) trademap of 2013 even shows that Vietnam is the world's fourth largest wood exporter (Trang and Thuy 2014).

Similar to other light industries, such as textile and garment industry and food and beverage industry mentioned above, the wood industry in Vietnam generally takes advantage of its abundant and cheap labour, and with virtue of its industrious workforce and a desire to upgrade, all of which are great advantages for the industry's development (Dinh et al. 2013). Alongside other advantages such as having a diversified and open market, and possessing better value than producers of other countries thanks to Vietnam's membership in the WTO and participation in multiple FTAs, these help to develop the export market of this industry.

Nevertheless, the small scale of both employees and investments in wood processing firms can significantly affect the sector's competitiveness and production stability. In addition, the small capital of the enterprises may also cause difficulties in responding to changes/ enhancements about the requirements/technical conditions in the export markets. Thus, Vietnam's wood processing sector faces many challenges. One such challenge is the outsourcing of the processing of furniture exports, with the designs provided by clients, and the owners not dynamic in products as well as markets. A second problem is low added value. Nearly all exporters are currently selling their products under the FOB production modality, which has low profits and cannot reach out to the supply chains overseas. The third problem is low labour productivity. These are three major problems that the wood processing industry in Vietnam needs to pay special attention to overcome.

Until now, the timer industry operates mainly in households, and in small and medium enterprises. Most of the workers are from rural areas, have difficulties in apprenticeship and are slow in adapting to the working style of modern environments (Trang and Thuy 2014). Thus, 
it is necessary to link with stakeholders to improve the skills of the workers and to incorporate the use of the latest and most effective techniques in production.

Therefore, in order to take advantage of the opportunities and continue to increase export turnover, enterprises should proactively make adjustments to standardize the production process, and design and produce products branded in Vietnam. There is a need to identify segments of the supply chain to focus on reorganizing the production process and to create products suited for the market. Besides, it is necessary to step up marketing and promotion of the products, as well as building up the distribution system.

\section{Survey on SMEs' Participation in Regional Economic Integration}

\section{Sample Characteristics}

The survey was conducted with enterprises in three manufacturing sectors with an aim to examine their participation in regional economic integration. They include 78 wooden products-making firms, 82 textile and garment firms, and 48 food and beverage firms (see Figure 9.7). The sample consists of 208 enterprises operating in five provinces in the north and the south of Vietnam - Hanoi, Bac Ninh, Ho Chi Minh city, Binh Duong, Dong Nai — which are hubs to the sampled

FIGURE 9.7

The Survey Sample

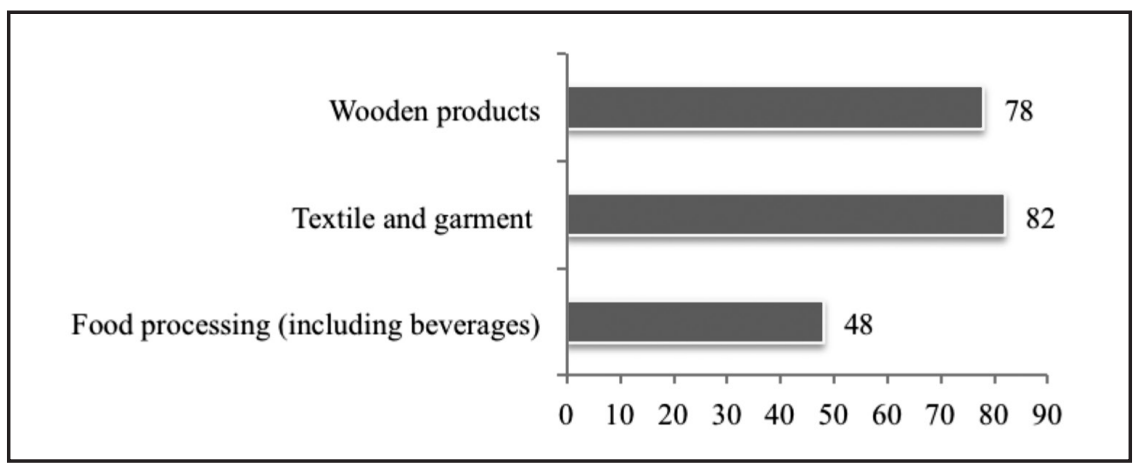

Source: Survey data. 
industries. The sample is chosen randomly based on the population of enterprises in the three sectors of the five provinces and cities provided by the General Statistics Office census survey. The SMEs surveyed in the research have been established since 2000. SMEs accounted for 90 per cent of total enterprises in the research sample.

Of the total of 208 enterprises, only 2.4 per cent are SOEs; the other 97.6 per cent are not. In terms of enterprise type, 0.5 per cent are partnership enterprises, 10.6 per cent are private companies, 57.7 per cent are limited liability companies, 27.9 per cent are joint stock companies, and 3.4 per cent are cooperatives (see Table 9.5). Limited liability companies accounted for the largest share across all enterprise size, from 54 per cent of small enterprises to 75 per cent of large ones. Table 9.5 shows that all large enterprises are in the textile and garment industry, a labour-intensive sector, and 75 per cent of them have total local domestic ownership with 75 per cent in the form of limited liability companies.

One of the outstanding features of the enterprises in the sample is the closeness of the business management and ownership. This is different from other countries where joint stock companies are the main type of establishment. The number of limited liability companies accounted for 57.7 per cent of the sample, while joint stock companies are the second largest, accounting for 27.9 per cent. More importantly, enterprises in the sample are dominantly owned by family members. Table 9.5 shows that while the number of private enterprises which are mainly family type of businesses accounted for 10.6 per cent of the sample, the number of enterprises which are managed by families is 55 per cent of the total enterprises in the sample. This may imply that cooperation among different investors is limited in Vietnamese enterprises.

Among the family-owned enterprises, 94 per cent are currently managed by the founder of the enterprises. With regard to academic qualification of the managers of these enterprises, 43.5 per cent have university degrees. The second largest group in terms of academic qualification is managers with secondary or high school education at 32.4 per cent.

Among the sampled enterprises, only 6 per cent have parent companies, of which 41 per cent are medium enterprises. In terms of membership of industry and business associations, 19 per cent of the 


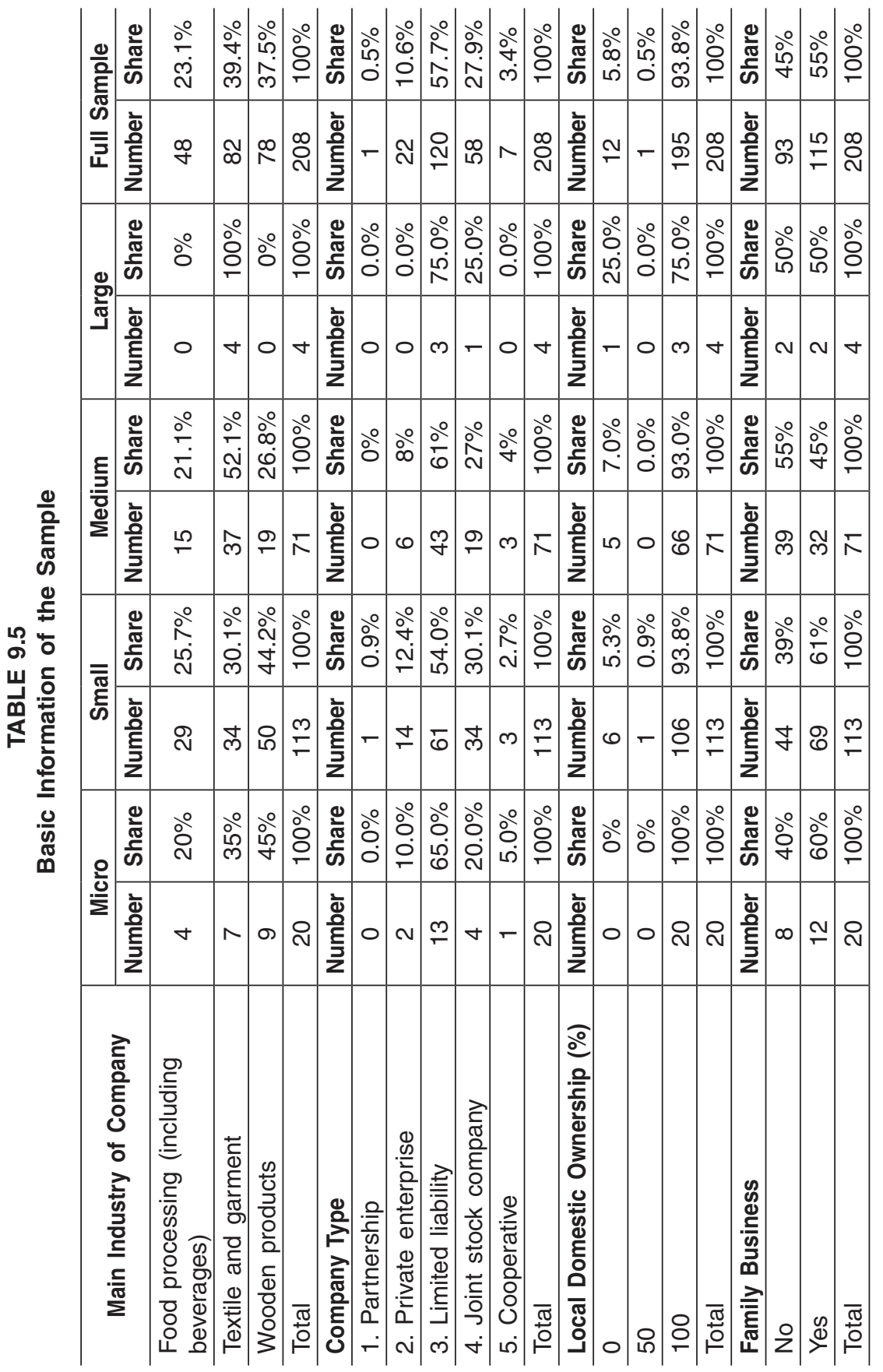




\begin{tabular}{|c|c|c|c|c|c|c|c|c|c|c|c|c|c|c|c|c|c|}
\hline है। & 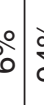 & $\begin{array}{c}\circ \\
\text { ơ } \\
\text { ô }\end{array}$ & ○̊ำ & $\begin{array}{l}\frac{\Phi}{\varpi ँ} \\
\frac{5}{\omega}\end{array}$ & $\mid \begin{array}{l}\stackrel{0}{2} \\
\hat{i} \\
m\end{array}$ & $\mid \begin{array}{l}\stackrel{0}{\wedge} \\
\dot{n} \\
\dot{m}\end{array}$ & $\mid \begin{array}{c}\circ \\
\stackrel{0}{d} \\
\text { लें }\end{array}$ & $\mid \begin{array}{l}0 \\
\circ \\
0 \\
0 \\
0\end{array}$ & 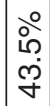 & ㅇํㅇ & $\begin{array}{l}\frac{\Phi}{\frac{ \pm}{\varpi}} \\
\frac{\bar{\sigma}}{\omega}\end{array}$ & $\begin{array}{l}\stackrel{0}{ } \\
\stackrel{+}{\sigma}\end{array}$ & 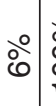 & 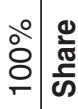 & $\frac{\circ}{\infty}$ & ๙̊ำ & ○̊ \\
\hline है & - & $\begin{array}{l}\infty \\
0 \\
\end{array}$ & $\stackrel{10}{\mp}$ & $\begin{array}{l}\frac{\grave{\Phi}}{E} \\
\bar{\Xi} \\
\bar{z}\end{array}$ & $\nabla$ & $\nabla$ & ది & $\stackrel{\infty}{-}$ & 于 & $\stackrel{\infty}{\circ}$ & 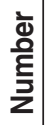 & 昌 & $\stackrel{N}{\sim}$ & 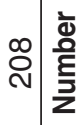 & 8 & ஓి & $\begin{array}{l}\infty \\
\text { ○ } \\
\text { | }\end{array}$ \\
\hline 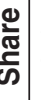 & $\overbrace{}^{\circ}$ & $\begin{array}{l}\circ \\
8 \\
8 \\
\\
\end{array}$ & $\begin{array}{l}\circ \\
\stackrel{\circ}{\circ} \\
\circ\end{array}$ & 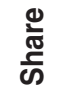 & $\mid \begin{array}{l}0 \\
\circ \\
0 \\
0\end{array}$ & $\begin{array}{l}0 \\
0 \\
0 \\
0\end{array}$ & ○̊ำ & $\begin{array}{l}0 \\
0 \\
0 \\
0\end{array}$ & $\begin{array}{l}\stackrel{0}{0} \\
0 \\
0\end{array}$ & 。ㅇ & $\begin{array}{l}\frac{\Phi}{\frac{2}{\varpi}} \\
\frac{\bar{c}}{\omega}\end{array}$ & 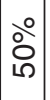 & 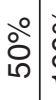 & 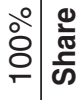 & $\stackrel{\circ}{\circ}$ & ㅇํㅇ & 영 \\
\hline$\xi$ & 0 & N & $N$ & 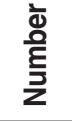 & 0 & 0 & $N$ & 0 & 0 & $\sim$ & 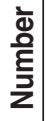 & $\sim$ & $N$ & ナ| & $n$ & - & 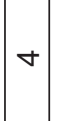 \\
\hline 离 & فُ & $\begin{array}{c}\circ \\
\vdots \\
0 \\
0\end{array}$ & ㅇํㅇ & 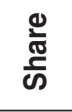 & \begin{tabular}{l}
0 \\
$\circ$ \\
0 \\
0 \\
\hdashline
\end{tabular} & $\begin{array}{l}0 \\
0 \\
0 \\
0\end{array}$ & 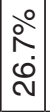 & $\begin{array}{l}0 \\
0 \\
0 \\
0 \\
-\end{array}$ & $\begin{array}{l}\stackrel{\circ}{\circ} \\
\stackrel{\rho}{\rho} \\
\stackrel{\rho}{0}\end{array}$ & ○̊․ & 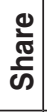 & ○े & $\stackrel{\circ}{\stackrel{2}{\Lambda}}$ & 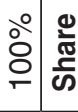 & $\stackrel{\circ}{\stackrel{\circ}{N}}$ & & 웅 \\
\hline$\underline{\underline{E}}$ & $N$ & প্লি| & ల్లి & 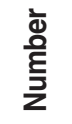 & ल & 0 & $\infty$ & m & $\stackrel{6}{\circ}$ & ஓ) & $\begin{array}{l}\frac{1}{\Phi} \\
\frac{0}{E} \\
\bar{\Sigma} \\
\frac{2}{z}\end{array}$ & $\mathscr{Q}$ & 10 & ๙ & 约 & $\stackrel{9}{-1}$ & $\bar{\lambda}$ \\
\hline 离 & $\hat{R}^{\circ}$ & ○ें & $\begin{array}{l}\circ \\
\stackrel{\circ}{\circ} \\
\circ\end{array}$ & $\begin{array}{l}\frac{0}{\varpi} \\
\frac{\tilde{\sigma}}{\omega}\end{array}$ & 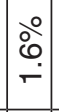 & 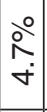 & $\begin{array}{l}\circ \\
\dot{0} \\
\dot{p} \\
\text { ले }\end{array}$ & $\begin{array}{c}0 \\
\infty \\
\infty \\
\infty \\
- \\
\end{array}$ & $\begin{array}{l}\text { o̊ } \\
0 \\
0 \\
\dot{+}\end{array}$ & ○̊ํ․ & 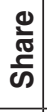 & $\begin{array}{l}\circ \\
8 \\
8\end{array}$ & $\stackrel{\circ}{\stackrel{\circ}{\forall}}$ & 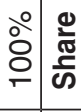 & 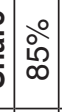 & مْ & $\begin{array}{l}\circ 0 \\
8 \\
\circ \\
\end{array}$ \\
\hline ह & ת & $\begin{array}{l}8 \\
6\end{array}$ & \&) & 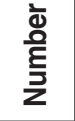 & - & $m$ & స్ & $\cong$ & $\stackrel{\mathrm{N}}{\mathrm{N}}$ & ఫे & $\begin{array}{l}\frac{1}{\mathbf{\Xi}} \\
\frac{\mathbf{0}}{\bar{\Xi}} \\
\bar{z}\end{array}$ & 음 & $\nabla$ & 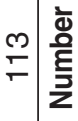 & 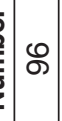 & 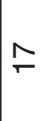 & $\frac{m}{\square}$ \\
\hline$\frac{\bar{\varpi}}{\tilde{\omega}}$ & 今̊ & ○̊ำ & $\begin{array}{l}\circ \\
\stackrel{\circ}{\circ} \\
\stackrel{-}{0}\end{array}$ & $\begin{array}{l}\frac{\Phi}{\frac{N}{J}} \\
\frac{c}{\omega}\end{array}$ & $\left|\begin{array}{l}\circ \\
0 \\
0 \\
0\end{array}\right|$ & $\begin{array}{l}\stackrel{\circ}{0} \\
\infty \\
\infty\end{array}$ & 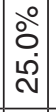 & 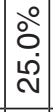 & 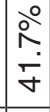 & ○̊ำ & 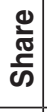 & ㅇํㅇ & i̊ & 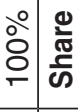 & \begin{tabular}{l}
$\circ$ \\
\hdashline \\
\end{tabular} & ○̊ & $\begin{array}{l}\circ 0 \\
\circ \\
0\end{array}$ \\
\hline 离 & D & $\stackrel{\sim}{\simeq}$ & $\cong$ & 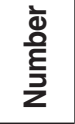 & 0 & - & m & m & 10 & $\stackrel{\sim}{\mp}$ & 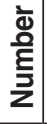 & $\stackrel{0}{1}$ & $\tau$ & ○ & $\infty$ & $\sim$ & ని \\
\hline 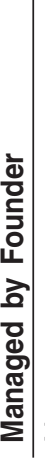 & & & 贾 & 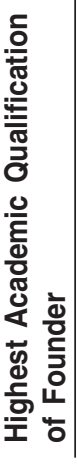 & 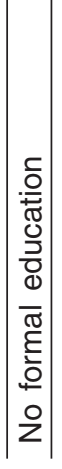 & 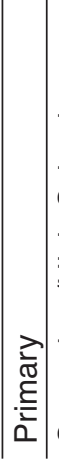 & 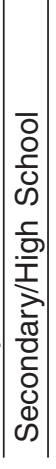 & 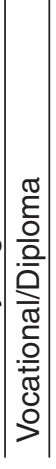 & 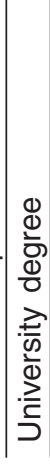 & $\mid$ & 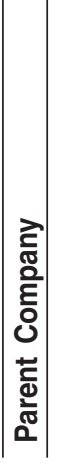 & & $\stackrel{\infty}{\mathbb{N}}$ & 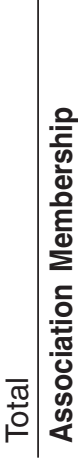 & 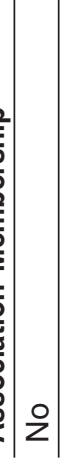 & $\stackrel{\infty}{\nu}$ & $\left|\begin{array}{l}\bar{\pi} \\
\stackrel{0}{0} \\
\end{array}\right|$ \\
\hline
\end{tabular}


enterprises in the sample reported that they have such memberships, 42 per cent of which are small and medium enterprises.

\section{Sales, Production Cost, Employment and Innovation}

Table 9.6 presents the sales activities of surveyed enterprises to their parent company, sister company, subsidiary company, other companies, SOEs, and directly to customers. Their outputs are divided into intermediate and final. In general, sales to parent company, sister company and subsidiary company are insignificant. Only 0.5 per cent, 0.5 per cent and 1 per cent of enterprises sell their intermediate outputs and 1.9 per cent, 1 per cent and 0.5 per cent sell their final products respectively to their parent company, sister company and subsidiary company. The largest customers of enterprises are other companies. Most interestingly, all large enterprises are involved in selling their final products to other companies. The fact that all large enterprises are in the textile and garment industry and all of them sell their final products to other companies means that all large enterprises outsourced the production of their final products to other companies. The remaining 33.3 per cent of large enterprises sell their intermediate outputs to other companies.

In total, 34.6 per cent of enterprises sell their intermediate products and 67.3 per cent of enterprises sell their final products to other companies. For SMEs, in terms of immediate outputs, 25 per cent of micro enterprises, 35.4 per cent of small enterprises and 36.1 per cent of medium enterprises sell their immediate outputs to other companies. Regarding final products, the share of total sales to other companies is large. Sixty-five per cent of micro enterprises, 68.1 per cent of small enterprises and 65.6 per cent of medium enterprises sell their final products to other companies.

The second most important customer is final consumers. In the survey, 57.7 per cent of enterprises reported that they sell their final products directly to consumers. Majority of small enterprises sell their final products directly to consumers (60.2 per cent), while 55 per cent of micro enterprises, 55.6 per cent of medium enterprises and 33.3 per cent of large enterprises sell final products to these customers.

SOEs are important customers of enterprises in the survey. About 9.6 per cent of enterprises sell their intermediate outputs to SOEs, while 23.6 per cent sell their final products to these customers. For SMEs, SOEs are important buyers of final products with 35 per cent of micro 


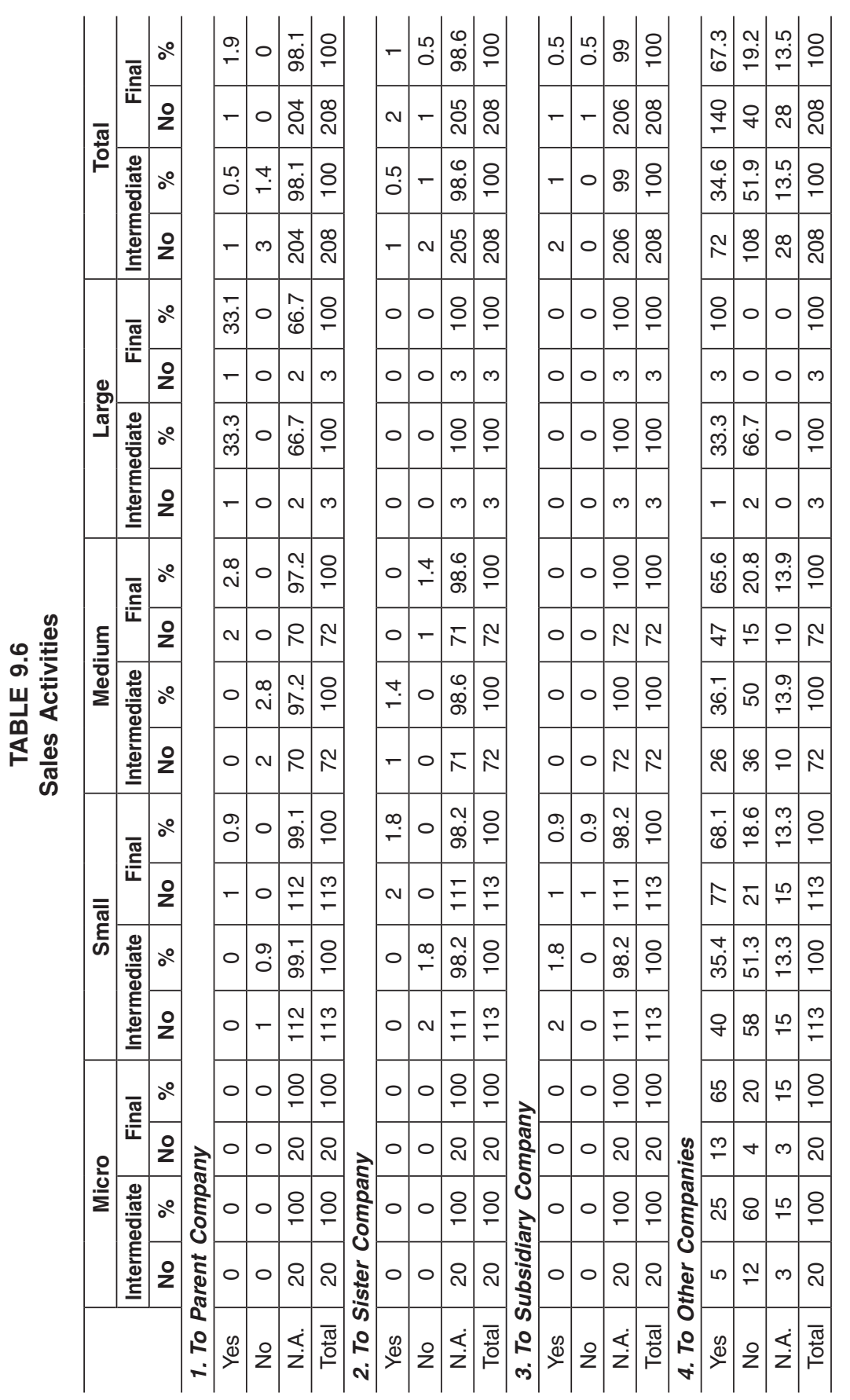




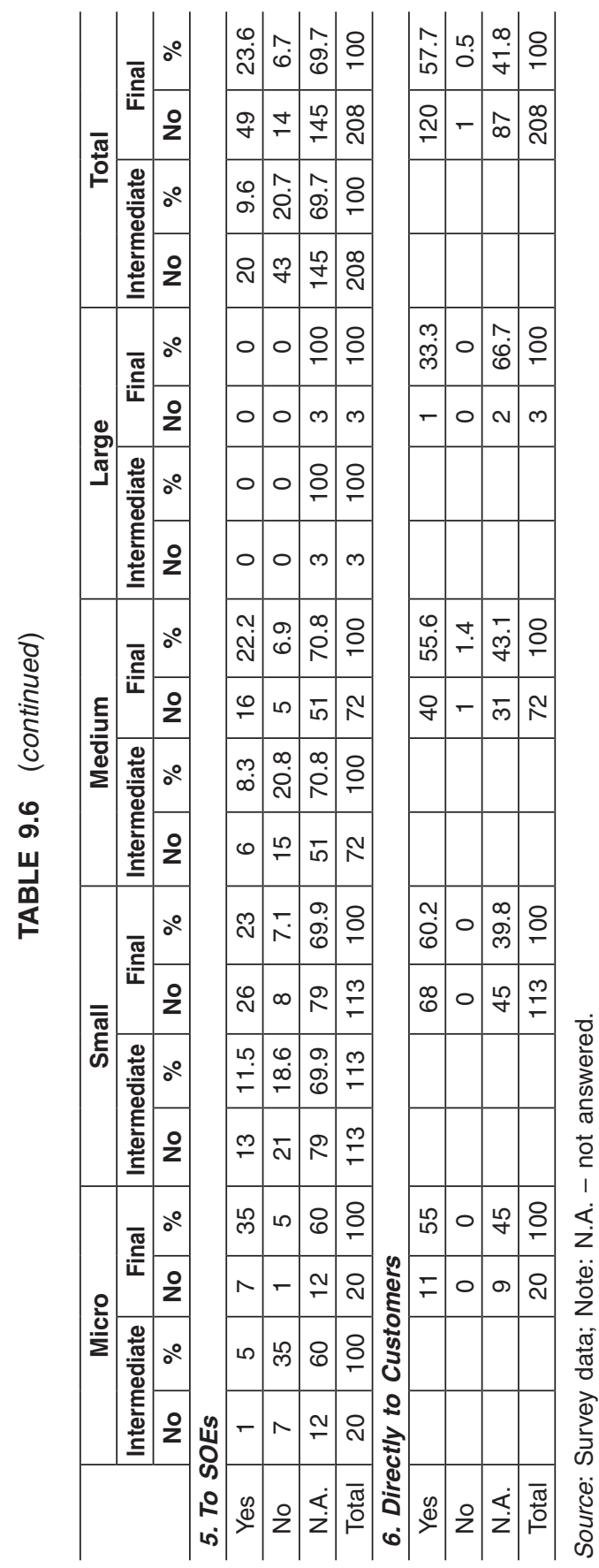


enterprises, 23 per cent of small enterprises and 22.2 per cent of medium enterprises sell their final outputs to SOEs. The share of SMEs selling their intermediate outputs to SOEs is much smaller. Large enterprises do not sell their products, either intermediate or final, to SOEs.

Table 9.7 shows that most of the enterprises carry out their production in-house. About 75.7 per cent of enterprises complete their outputs totally in-house, 2.4 per cent completely outsource their production activities and 21.8 per cent use both in-house and outsourced production. Regarding large enterprises, 100 per cent of them use in-house production. Among SMEs, 75.3 per cent have completely in-house production and only 2.5 per cent completely outsource their production. The share of SMEs using both in-house and outsourced production is 22.2 per cent.

In terms of production costs, raw materials accounted for the largest share of the total production costs at 40.62 per cent in 2013 and 41.14 per cent in 2014. While SMEs have very similar share of raw materials in production costs, large enterprises spend less on raw materials. Large enterprises spent 31.25 per cent of the total production costs on raw materials in both 2013 and 2014. These figures are lower than those of SMEs.

The second largest item in production costs of the surveyed enterprises is salaries and wages. In 2013, salaries and wages accounted for 22.61 per cent of total production costs; for 2014 the figure is 22.7 per cent. Among types of enterprises, salaries and wages of micro enterprises are the lowest, accounting for 16 per cent and 16.1 per cent of total production costs for 2013 and 2014 respectively. Compared with other types of enterprises, large enterprises pay more for salaries and wages. They accounted for 27.5 per cent in both 2013 and 2014.

Intermediate inputs are the third largest item in production costs of responded enterprises. They contributed 17.53 per cent in 2013 and 17.04 per cent in 2014 of the total costs of all enterprises. Large and micro enterprises pay higher share for intermediate input compared to small and medium firms. For large enterprises, it is intermediate inputs and not salaries and wages that are the second largest item in production costs.

In terms of sources for inputs in 2014, the survey results show that most of the enterprises use local inputs. The share of enterprises that use 75 to 100 per cent local inputs is 77.3 per cent. But the share of enterprises that use local inputs of less than 25 per cent is also 


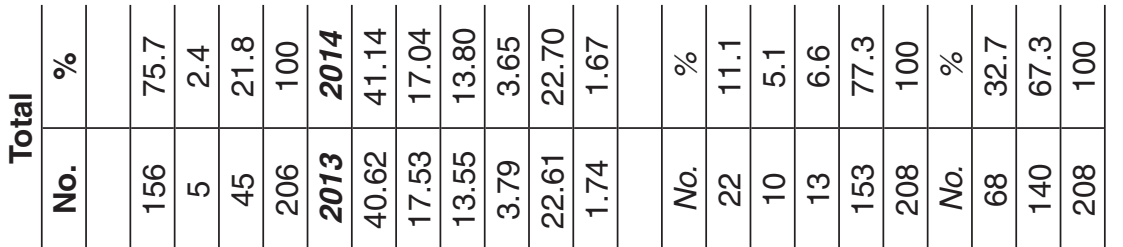

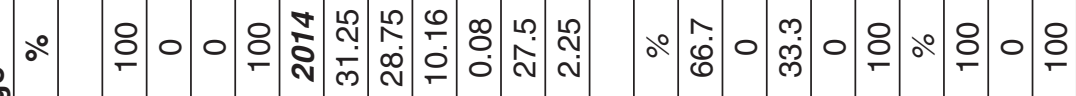

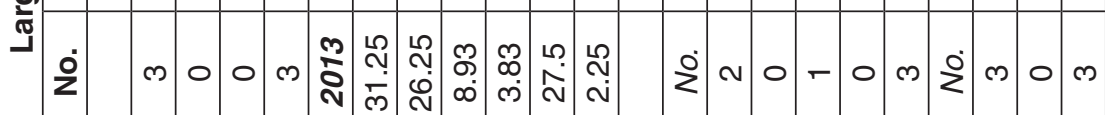

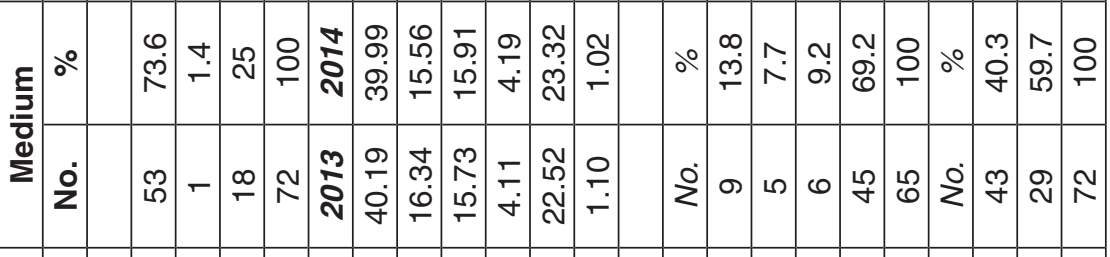

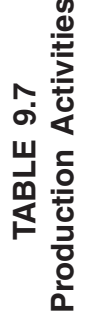

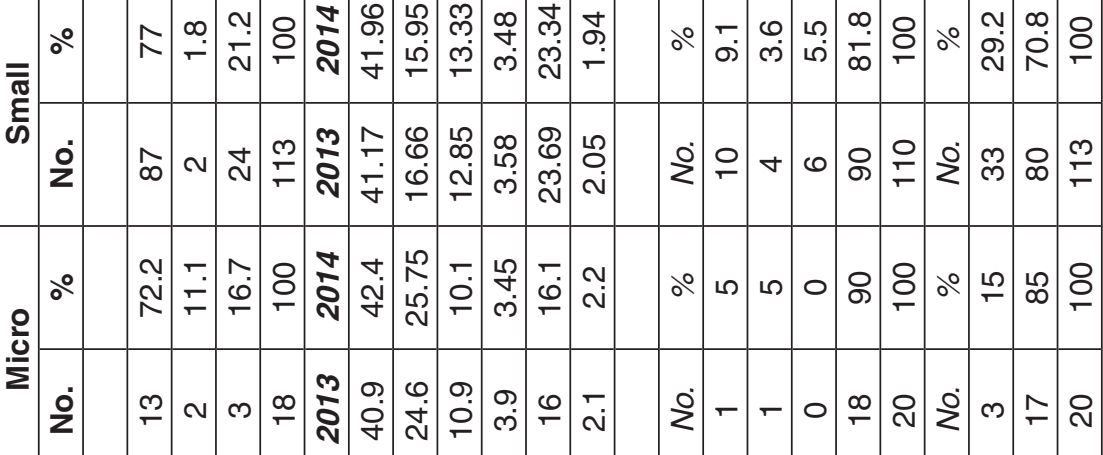

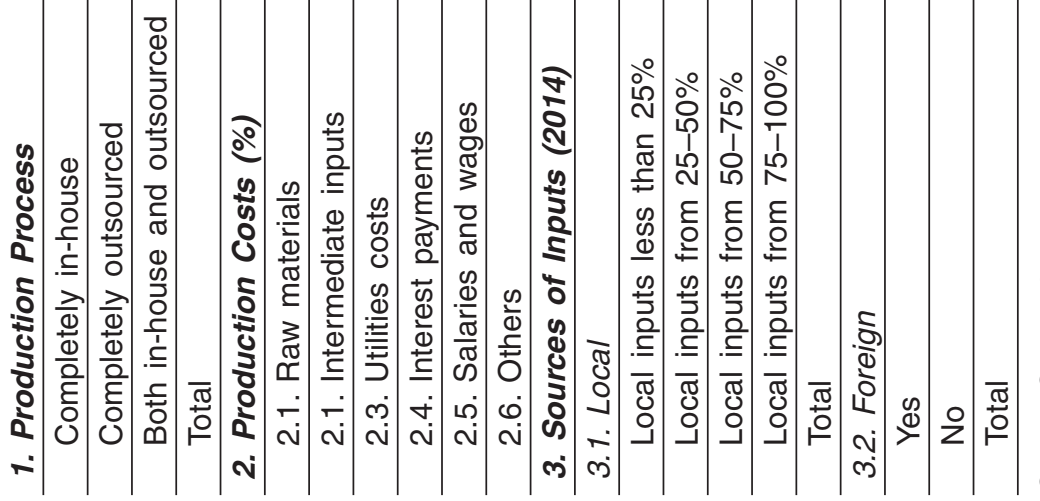

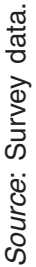


significant at 11.1 per cent in 2014. Micro and small enterprises seemed to depend on local inputs for their production. The number of micro and small enterprises that use 75 to 100 per cent local inputs are 90 per cent and 81.8 per cent respectively. Large enterprises, however, are different. The share of large enterprises that use less than 25 per cent of local inputs accounted for 66.7 per cent.

The number of enterprises that use foreign inputs for their production is significant. The survey statistics shows that 32.7 per cent of enterprises use imported inputs. Hundred per cent of large enterprises use imported inputs, while 40.3 per cent of medium enterprises use imported inputs. Only 15 per cent of micro enterprises use foreign inputs for their production.

In terms of employment, responded enterprises employ on average 52.92 full-time and 17.92 part-time labours in 2013 and 56.4 full-time and 19.74 part-time labour in 2014 (see Table 9.8). There is a trend of expansion in terms of firm size during 2013 and 2014 from the employment aspect. Female workers accounted for more than 50 per cent of the total employees in surveyed enterprises. Large enterprises use more female workers than male workers. The shares of female workers in large enterprises are 68.3 per cent in 2013 and 71.6 per cent in 2014. Foreign workers accounted for a tiny share of the total number of workers. In 2013, foreign workers accounted for 5.6 per cent of total labour and this reduced to 0.4 per cent in 2014 .

The largest share of employment comes from plant and machine operators, and assemblers. They accounted for 61 per cent of total employees, but earned only 46 per cent of total salaries and wages on average. Service and sales employees accounted for the second largest share in total employment at 14 per cent. Supervisory and clerical employees accounted for the third largest share and managers and professionals accounted for the fourth largest share of total employment.

The survey shows that the better paid employees are engineers and technicians, who accounted for 4 per cent of employment but 9 per cent of salaries and wages. Next are service and sales employees who made up 14 per cent of total employees but earned 22 per cent of salaries and wages of an average firm. The third better paid group is managers and professionals, who earned 13 per cent of the total salaries and wages while made up only 8 per cent of total employment. Supervisory and clerical employees are relative well earned since their 


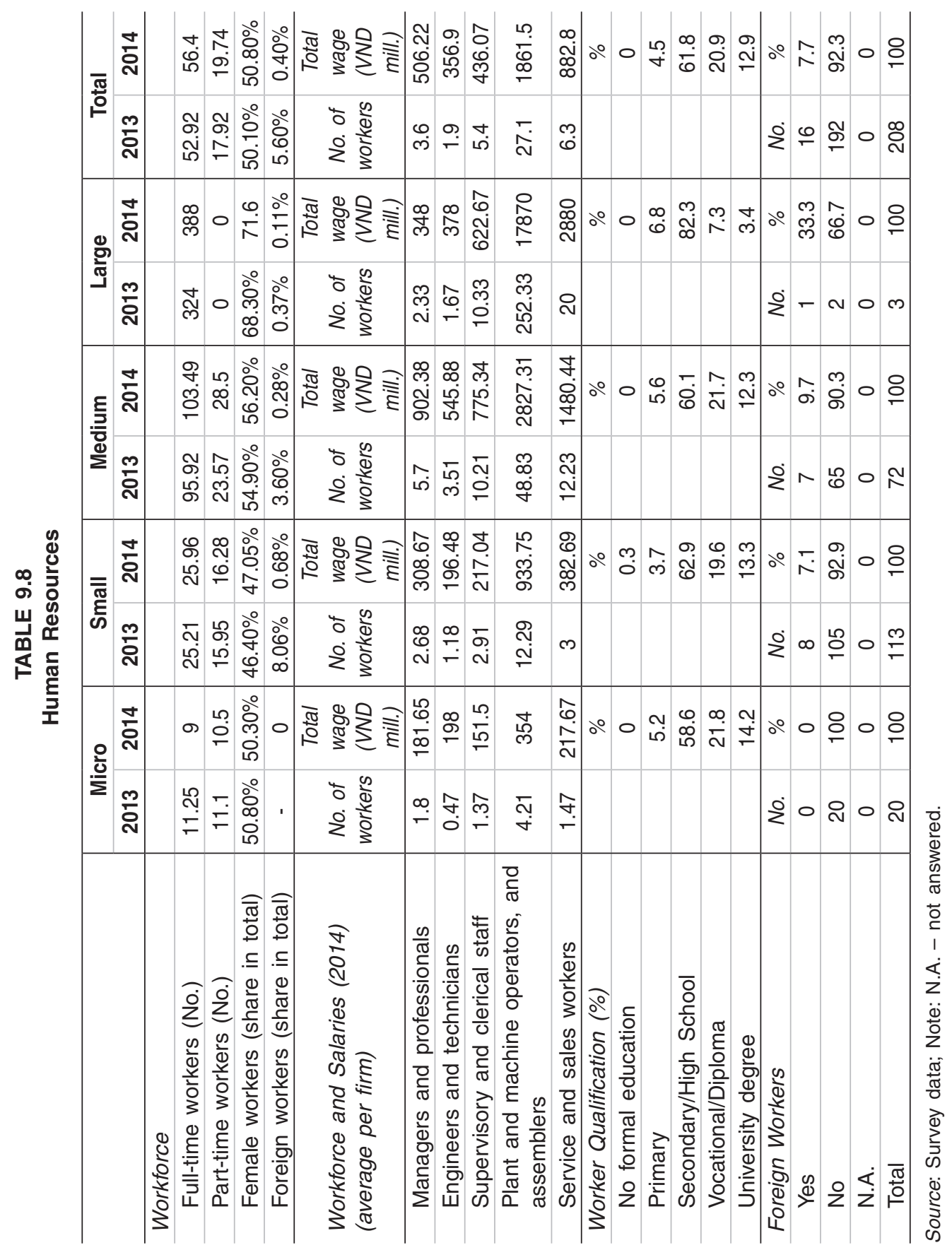


12 per cent of employment accounted for 11 per cent of salaries and wages. The group of employees that earned the least is plant and machine operators, and assemblers.

In terms of education, employees of surveyed enterprises have good qualifications. About 33.8 per cent of them have vocational/ diploma or university and higher degrees. Workers who attended secondary and high schools accounted for 61.8 per cent of total employment. The survey also shows that hiring foreign workers is not popular in these three manufacturing sectors. Only 7.7 per cent of enterprises hire foreign workers and not a single micro enterprise has this practice.

Table 9.9 shows innovation expenditure, innovation activities and turnover from new products and services of enterprises in the survey. In terms of innovation expenditure, the mean expenditure for in-house $R \& D$ of an average enterprise is 10 per cent of total expenditure for innovation during the period 2012-14. Outsourcing R\&D activities has an insignificant share of less than 1 per cent of total innovation expenditure of an average enterprise. Micro and medium firms do not spend on outsourcing R\&D activities. Acquisition of machinery, equipment and software is the largest share of expenditure for innovation, at 88.3 per cent. Acquisition of external knowledge requires only 1 per cent of total expenditure for innovation.

Among the responded enterprises, medium enterprises spend the most on acquisition of machinery, equipment and software. An average medium enterprise spends about VND 7.53 billion on machinery, equipment and software while it spends only VND 0.78 billion on in-house R\&D activities. They do not spend on outsourcing R\&D activities and spend very little on acquisition of external knowledge. Large enterprises, in contrast, spend largely on in-house R\&D activities, with an average of VND 2.67 billion while they spent VND 1 billion on machinery, equipment and software during 2012-14.

In terms of innovation activities, the most popular activity is producing new or significantly improved goods. About 51.4 per cent of enterprises stated that they have such activities. Only 7.7 per cent of enterprises said that they produced new or significantly improved services during 2012-14. In 2014, the turnover from products that are new to market of an average enterprise is quite high: 45.8 per cent. The turnover from products that are new to firm is also high, at 44.9 per cent. 


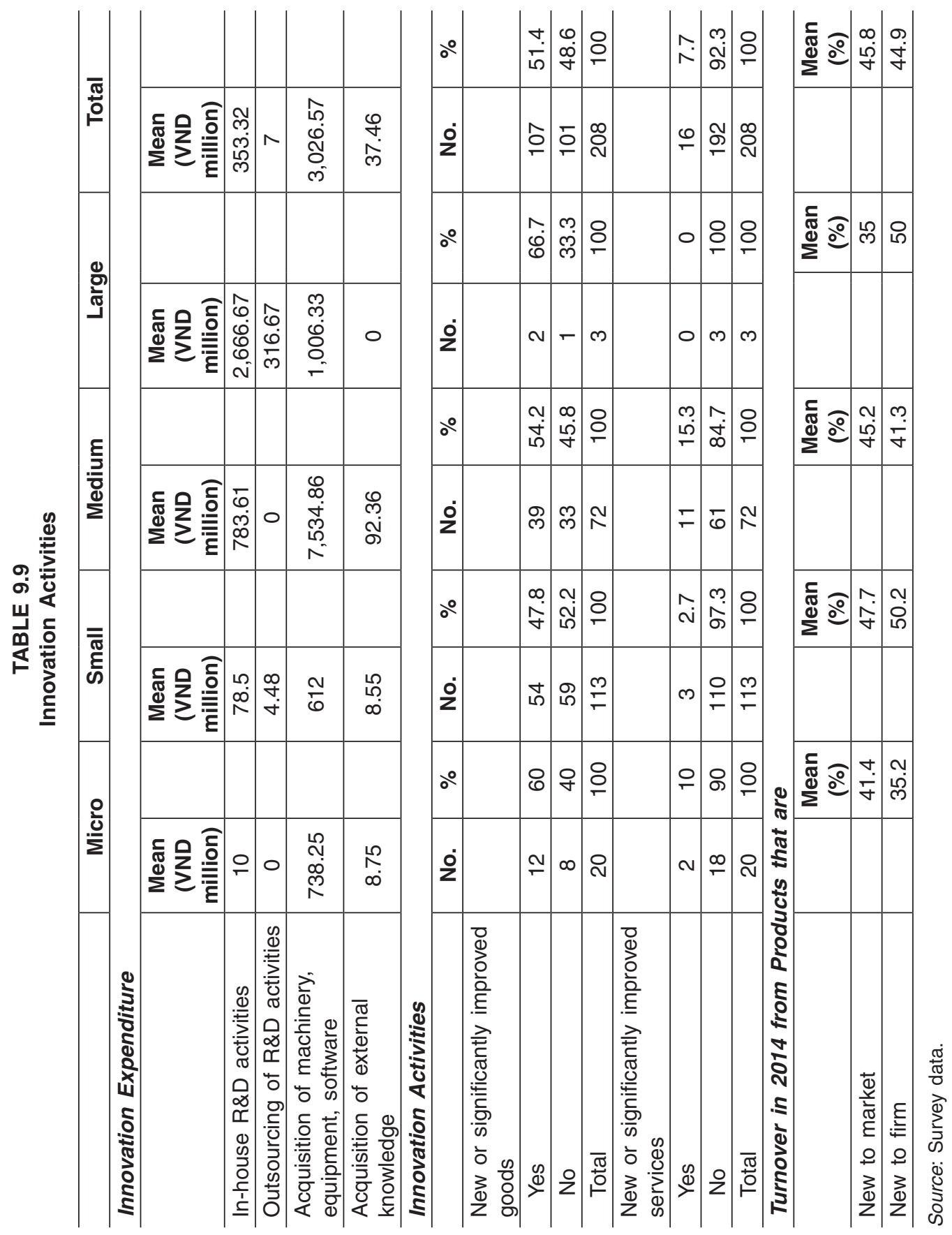




\section{Regional Trade Participation}

The survey results show that 85 per cent of enterprises in all three manufacturing sectors do not participate in international trade. This share is distributed fairly equal among the three sectors of which the shares of food and beverage enterprises, textile and garment enterprises, and wooden product enterprises are 85.4 per cent, 85.4 per cent and 83.3 per cent respectively (see Table 9.10).

TABLE 9.10

International Trade Participation

\begin{tabular}{|c|c|c|c|c|c|}
\hline & & $\begin{array}{c}\text { Food \& } \\
\text { Beverage } \\
\text { Enterprises }\end{array}$ & $\begin{array}{c}\text { Textile and } \\
\text { Garment } \\
\text { Enterprises }\end{array}$ & $\begin{array}{c}\text { Wooden } \\
\text { Product } \\
\text { Enterprises }\end{array}$ & Total \\
\hline \multicolumn{6}{|c|}{ International Trade Activities } \\
\hline \multirow{2}{*}{$\begin{array}{l}\text { Not participating in } \\
\text { international trade }\end{array}$} & No. & 41 & 70 & 65 & 176 \\
\hline & $\%$ & 85.4 & 85.4 & 83.3 & 84.6 \\
\hline \multirow{2}{*}{$\begin{array}{l}\text { Participating in } \\
\text { international trade }\end{array}$} & No. & 7 & 12 & 13 & 32 \\
\hline & $\%$ & 14.6 & 14.6 & 16.7 & 15.4 \\
\hline \multirow{2}{*}{ Total } & No. & 48 & 82 & 78 & 208 \\
\hline & $\%$ & 100 & 100 & 100 & 100 \\
\hline \multicolumn{6}{|c|}{ Importing from ASEAN Countries } \\
\hline \multirow{2}{*}{ Not importing } & No. & 47 & 76 & 72 & 195 \\
\hline & $\%$ & 97.9 & 92.7 & 92.3 & 93.75 \\
\hline \multirow{2}{*}{ Importing } & No. & 1 & 6 & 6 & 13 \\
\hline & $\%$ & 2.1 & 7.3 & 7.7 & 6.25 \\
\hline \multirow{2}{*}{ Total } & No. & 48 & 82 & 78 & 208 \\
\hline & $\%$ & 100 & 100 & 100 & \\
\hline \multicolumn{6}{|c|}{ Exporting to ASEAN Countries } \\
\hline \multirow{2}{*}{ Not exporting } & No. & 43 & 75 & 73 & 191 \\
\hline & $\%$ & 89.6 & 91.5 & 93.6 & 91.8 \\
\hline \multirow{2}{*}{ Exporting } & No. & 5 & 7 & 4 & 16 \\
\hline & $\%$ & 10.4 & 8.5 & 5.1 & 7.69 \\
\hline \multirow{2}{*}{ Total } & No. & 48 & 82 & 78 & 208 \\
\hline & $\%$ & 100 & 100 & 100 & \\
\hline
\end{tabular}

Source: Survey data.

In terms of import and export to ASEAN countries, in total only 6.25 per cent of enterprises import from ASEAN countries and 7.69 per cent export to ASEAN economies. With regards to importing from 
ASEAN countries, 2.1 per cent of food and beverage enterprises, 7.3 per cent of textile and garment enterprises and 7.7 per cent of wooden product enterprises import from these countries. In terms of exporting to ASEAN countries, 10.4 per cent of food and beverage enterprises, 8.5 per cent of textile and garment enterprises, and 5.1 per cent of wooden product enterprises export to these countries.

\section{Awareness of $A E C$ and Its Impacts}

About 15.4 per cent of total enterprises have business relations with enterprises in other ASEAN countries (see Table 9.11). This means that the majority of 84.6 per cent of enterprises do not have such business relations. The participation of surveyed enterprises in regional trade is therefore limited. In terms of awareness of AEC, 58 per cent of total enterprises are aware, while 42 per cent stated they are not. However, in terms of ASEAN policies and strategies for SMEs, only 25 per cent of the total enterprises are aware, while 75 per cent are not. Hence, there is a lack of awareness of ASEAN policies and strategies for SMEs in Vietnam.

TABLE 9.11

Awareness of the ASEAN Economic Community and Its Policies

\begin{tabular}{|c|c|c|c|c|c|c|c|c|c|c|}
\hline \multirow[t]{2}{*}{ AEC Awareness } & \multicolumn{2}{|c|}{$\begin{array}{c}\text { Full } \\
\text { Sample }\end{array}$} & \multicolumn{2}{|c|}{ Micro } & \multicolumn{2}{|c|}{ Small } & \multicolumn{2}{|c|}{ Medium } & \multicolumn{2}{|c|}{ Large } \\
\hline & No. & $\%$ & No. & $\%$ & No. & $\%$ & No. & $\%$ & No. & $\%$ \\
\hline \multicolumn{11}{|c|}{ Business Relations with Firms in ASEAN } \\
\hline Yes & 32 & 15.4 & 1 & 5 & 14 & 12.4 & 16 & 22.2 & 1 & 33.3 \\
\hline No & 176 & 84.6 & 19 & 95.0 & 99 & 87.6 & 56 & 77.8 & 2 & 66.7 \\
\hline N.A. & 208 & & 20 & & 113 & & 72 & & 3 & \\
\hline
\end{tabular}

Awareness of AEC Policy Blueprint/Strategic Action Plan for SME Development 2004-2014

\begin{tabular}{l|c|c|c|c|c|c|c|c|c|c}
\hline Yes & 155 & 25.1 & 18 & 90 & 81 & 72.3 & 54 & 75 & 2 & 66.7 \\
\hline No & 52 & 74.9 & 2 & 10 & 31 & 27.7 & 18 & 25 & 1 & 33.3 \\
\hline Total & 207 & 100 & 20 & & 112 & & 72 & & 3 & \\
\hline Awareness of ASEAN Economic Community \\
\hline Yes & 120 & 58 & 8 & 40 & 66 & 58.4 & 44 & 62 & 2 & 66.7 \\
\hline No & 87 & 42 & 12 & 60 & 47 & 41.6 & 27 & 38 & 1 & 33.3 \\
\hline Total & 207 & 100 & 20 & & 113 & & 71 & & 3 & \\
\hline
\end{tabular}

Source: Survey data. 
In terms of the perception of the influences of the AEC, the surveyed enterprises said that there is an increase in domestic revenue, export sales, profits, market competitiveness and access to intermediate outputs. Particularly, 45.2 per cent of the enterprises stated that their domestic revenue increased, 66.7 per cent said their export sales went up, 73.8 per cent answered that their profits rosed, 69 per cent stated that their competitiveness in domestic market increased, and 61.9 per cent confirmed that their competitiveness in the international market increased. Meanwhile, another benefit of the AEC is lowering import expenses. About 59.5 per cent of total enterprises stated that AEC reduced their import costs (see Tables 9.12 and 9.13). The AEC, therefore, has much influence on the businesses of the surveyed enterprises.

The perceptions of the impact of AEC on businesses are different in different sectors. About 47.4 per cent of textile and garment firms and 50 per cent of wooden products manufacturing firms said that domestic sales will increase with AEC. However, only 28.6 per cent of food and beverage firms believed that there will be such an increase. In terms of export sales, majority of firms in all three sectors believed that there will be an increase. About 71.4 per cent of food and beverages enterprises, 78.9 per cent of textile and garment enterprises, and 50 per cent of wooden products manufacturing firms said that there will be an increase in export sales.

Majority of the firms believed that there will be increases in competition, both at home and abroad. At the same time, there will be greater access to intermediate outputs for firms across all three sectors. For import cost, majority of the firms, except large firms, believed that AEC will bring about a decrease (see Tables 9.12 and 9.13).

From the perspective of enterprise size with regards to the impacts of AEC, Table 9.13 shows that the majority of small and medium firms believe in an increase in domestic sales with AEC. However, 75 per cent of micro firms believe that there will be no change and 33.3 per cent of medium firms believe in a decrease in domestic sales. In terms of export sales, 50 per cent of micro firms believe in an increase but the same share of firms also believes in no change in export sales. In contrast, majority of small and medium firms believe in an increase in export sales. 


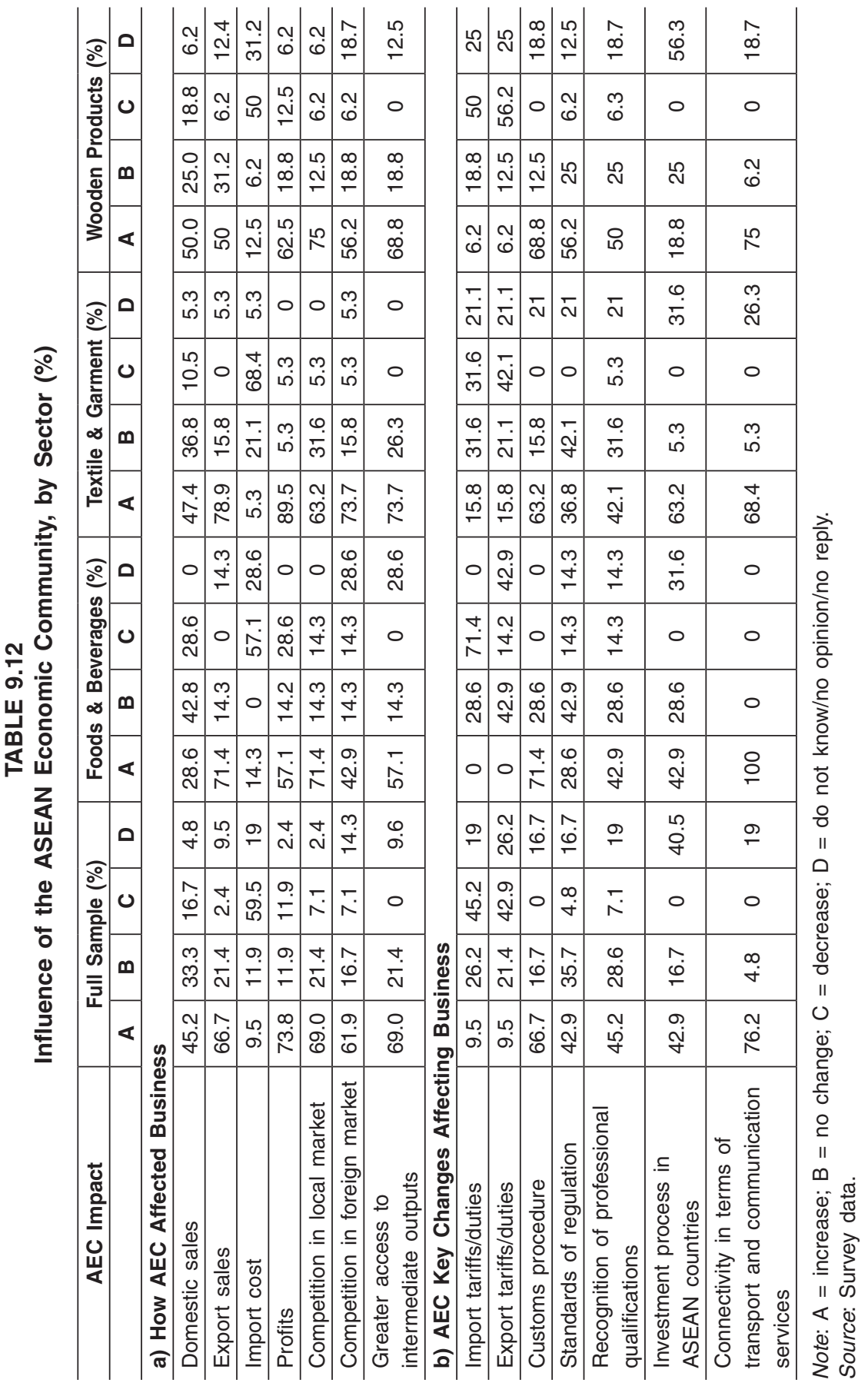




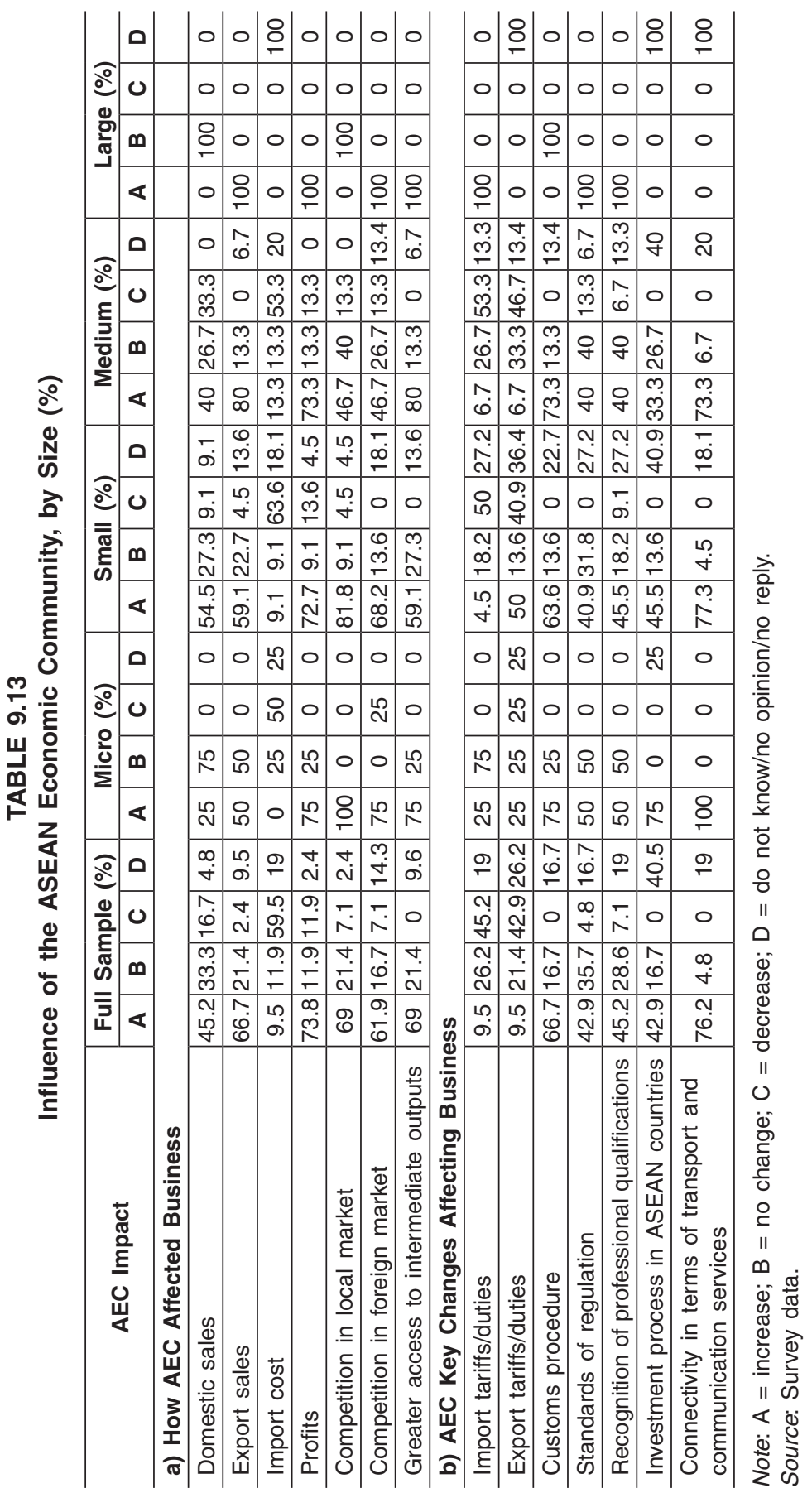




\section{Key Changes in AEC Affecting Businesses}

Tables 9.12 and 9.13 also show the possible changes caused by AEC that will influence the businesses of firms in the three sectors. In general, 45.2 per cent and 42.9 per cent of the surveyed firms indicate a decrease in import duties and a decrease in export duties, respectively as the key changes affecting their businesses. On the other hand, 66.7 per cent of firms believe in an increase in custom procedures, 42.9 per cent an increase of standards of regulation, 45.2 per cent an increase of recognition of professional qualifications, 42.9 per cent an increase of investment process, and 76.2 per cent an increase in connectivity in transportation and communication services as a result of the AEC.

For import duties, 75 per cent of micro firms believe in no change, while 50 per cent of small firms and 53.3 per cent of medium firms believe in a decrease. With regard to export duties, micro firms do not exhibit a trend, while 40.9 per cent of small firms and 46.7 per cent of medium firms believe in a decrease in export duties as a key impact on their businesses. On other changes, majority of SME firms believe in an increase in custom procedures, increase in standards of regulation, increase in recognition of professional qualifications, increase in investment process, and increase in connectivity in transportation and communication services as the key impacts affecting their businesses (see Table 9.13).

\section{Utilization of FTAs and Their Influences}

Table 9.14 shows that the surveyed firms are not well aware of FTAs. Less than half of the surveyed firms (42.3 per cent) are aware of FTAs. It is surprising that only 25 per cent of large firms are aware of FTAs. The type of enterprises that is most aware of FTAs is the medium enterprises with 50.7 per cent of them being aware of the FTAs between Vietnam and other countries.

The use of FTAs is very limited. Among 88 enterprises which are aware of FTAs, only 14 of them, or 15.9 per cent, are FTA users. All large enterprises that are aware of FTAs use such trade agreements. The next highest user of FTAs, surprisingly, is micro enterprises with 28.6 per cent of them which are aware of FTAs are FTA users. Among the FTA users, 42.9 per cent use only a single FTA while 57.1 per cent use more than one FTA. 
TABLE 9.14

Awareness of FTAs

\begin{tabular}{|c|c|c|c|c|c|c|c|c|c|c|}
\hline & \multicolumn{2}{|c|}{$\begin{array}{c}\text { Full } \\
\text { Sample }\end{array}$} & \multicolumn{2}{|c|}{ Micro } & \multicolumn{2}{|c|}{ Small } & \multicolumn{2}{|c|}{ Medium } & \multicolumn{2}{|c|}{ Large } \\
\hline & No. & $\%$ & No. & $\%$ & No. & $\%$ & No. & $\%$ & No. & $\%$ \\
\hline \multicolumn{11}{|l|}{ Awareness of FTAs } \\
\hline Yes & 88 & 42.3 & 7 & 35 & 44 & 38.9 & 36 & 50.7 & 1 & 25 \\
\hline No & 120 & 57.6 & 13 & 65 & 69 & 61.1 & 35 & 49.3 & 3 & 75 \\
\hline Total & 208 & 100 & 20 & 100 & 113 & 100 & 71 & 100 & 4 & 100 \\
\hline \multicolumn{11}{|l|}{ Use of FTAs } \\
\hline FTA Users & 14 & 15.9 & 2 & 28.6 & 5 & 11.4 & 6 & 16.7 & 1 & 100 \\
\hline Non-users & 74 & 84.1 & 5 & 71.4 & 39 & 88.6 & 30 & 83.3 & 0 & 0 \\
\hline Total & 88 & 100 & 7 & 100 & 44 & 100 & 36 & 100 & 1 & 100 \\
\hline \multicolumn{11}{|l|}{ Number of FTAs Used } \\
\hline Single FTA & 6 & 42.9 & 1 & 50 & 1 & 20 & 4 & 66.7 & 0 & 0 \\
\hline $\begin{array}{l}\text { More than one FTA } \\
\text { used }\end{array}$ & 8 & 57.1 & 1 & 50 & 4 & 80 & 2 & 33.3 & 1 & 100 \\
\hline Total & 14 & 100 & 2 & 100 & 5 & 100 & 6 & 100 & 1 & 100 \\
\hline \multicolumn{11}{|l|}{ Reasons for Not Using FTA } \\
\hline $\begin{array}{l}\text { Small trade volume with } \\
\text { other countries }\end{array}$ & 23 & 25 & 1 & 16.7 & 14 & 25.5 & 8 & 25.8 & 0 & 0 \\
\hline $\begin{array}{l}\text { Lack of knowledge/do } \\
\text { not know how to use }\end{array}$ & 25 & 27.2 & 2 & 33.3 & 18 & 32.7 & 5 & 16.1 & 0 & 0 \\
\hline $\begin{array}{l}\text { Difficult to get certificate } \\
\text { of origin }\end{array}$ & 5 & 5.4 & 0 & 0 & 4 & 7.3 & 1 & 3.2 & 0 & 0 \\
\hline $\begin{array}{l}\text { Small tariff preference } \\
\text { by FTA }\end{array}$ & 3 & 3.3 & 0 & 0 & 2 & 3.6 & 1 & 3.2 & 0 & 0 \\
\hline $\begin{array}{l}\text { Difficult to fulfil the } \\
\text { requirements of Rules } \\
\text { of Origin }\end{array}$ & 3 & 3.3 & 0 & 0 & 2 & 3.6 & 1 & 3.2 & 0 & 0 \\
\hline Others & 33 & 35.9 & 3 & 50 & 15 & 27.3 & 15 & \begin{tabular}{|l|}
48.4 \\
\end{tabular} & 0 & 0 \\
\hline Total & 92 & 100 & 6 & 100 & 55 & 100 & 31 & 100 & 0 & 0 \\
\hline
\end{tabular}

Source: Survey data.

Among the FTA non-users who are aware of the trade agreements, three reasons that are most often cited for not using FTAs are (i) small trade volume with other countries, (ii) lack of knowledge, and (iii) other reasons. These same three reasons are also observed across the different firm sizes. 


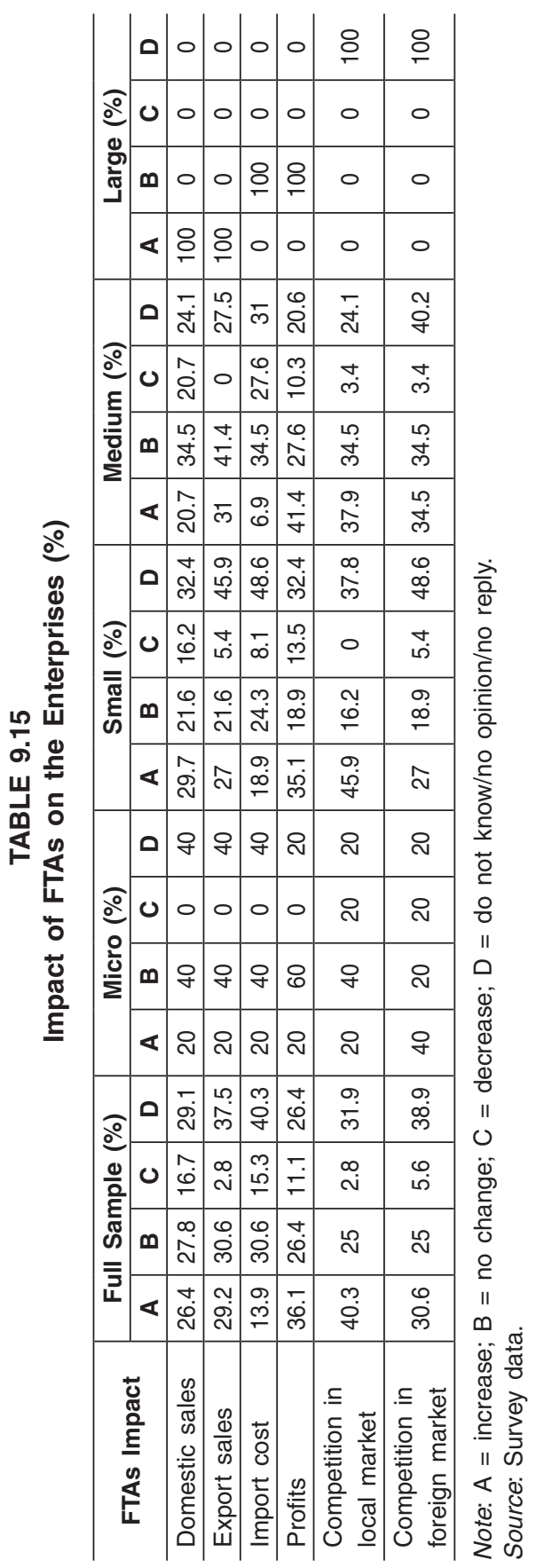


Regarding the impacts of FTAs on enterprises, Table 9.15 shows that most enterprises believe that domestic sales, export revenue and import expense will remain the same under the FTAs. About 27.8 per cent of enterprises said that domestic sales remain unchanged, 30.6 per cent stated that export revenue stays the same, and 30.6 per cent reported that import expenses are unchanged. However, the surveyed enterprises believed that there are significant changes in competition in the domestic market, with 40.3 per cent of them stating that competitiveness in domestic market has increased as a result of the FTAs. Also, the enterprises believed that competition in foreign markets will increase, although a large portion of the surveyed firms stated that they do not know or have no reply to this question.

\section{The State Participation Promotion Policies at Regional and National Levels}

It can be seen from Table 9.16 that there is little support from the central, city and local authorities for participating in overseas events (e.g. fairs, exhibitions) as well as in meeting with potential partners. A large number of enterprises also indicated "non applicable" in

TABLE 9.16

Government Support

\begin{tabular}{l|l|c|c|c}
\hline \multirow{2}{*}{ Forms of Support from Government } & \multicolumn{3}{c}{ Governmental level } \\
\cline { 3 - 5 } \multicolumn{2}{c|}{} & $\begin{array}{c}\text { Central } \\
(\%)\end{array}$ & $\begin{array}{c}\text { Provincel } \\
\text { City (\%) }\end{array}$ & $\begin{array}{c}\text { Local } \\
(\%)\end{array}$ \\
\hline \multirow{2}{*}{$\begin{array}{l}\text { Support for participation in } \\
\text { overseas events (e.g. fairs, } \\
\text { exhibitions) }\end{array}$} & Support & 3.8 & 3.4 & 5.8 \\
\cline { 2 - 5 } & No support & 2.9 & 3.4 & 1 \\
\cline { 2 - 5 } $\begin{array}{l}\text { Support in meeting with } \\
\text { potential partners }\end{array}$ & Not applicable & 93.3 & 93.3 & 93.3 \\
\cline { 2 - 5 } & Support & 1.9 & 1.9 & 3.8 \\
\cline { 2 - 5 } & No support & 2.4 & 2.4 & 0.5 \\
\cline { 2 - 5 } & Not applicable & 95.7 & 95.7 & 95.7 \\
\hline \multirow{3}{*}{$\begin{array}{l}\text { Financial support } \\
\text { Support in expanding }\end{array}$} & Support & 0.5 & 2.4 & 0 \\
\cline { 2 - 5 } $\begin{array}{l}\text { business overseas through } \\
\text { international agreements }\end{array}$ & No support & 2.4 & 0.5 & 2.9 \\
\cline { 2 - 5 } & Not applicable & 97.1 & 97.1 & 97.1 \\
\cline { 2 - 5 } & Support & 0 & 1 & 0 \\
\cline { 2 - 5 } & No support & 1 & 0 & 1 \\
\hline
\end{tabular}

Source: Survey data. 
receiving support for financial assistance and in business expansion. Thus, the support from the government remains to be seen.

The surveyed enterprises also raised issues on the impact of ASEAN economic integration on their businesses, competition between businesses in the region, and difficulties and obstacles when participating in providing intermediate goods for domestic and international enterprises.

The advantages enjoyed by businesses that have been participating in regional trade, production and investment include:

- In the process of regional economic integration, cheap labour and raw materials become available, and there are opportunities to work with capable affiliates and foreign companies.

- The market for local firms expanded as a result of ASEAN economic integration.

- Labour quality rose to meet the requirements of businesses.

- The expansion of production, business and investment, and regional market created new jobs.

However, there are certain difficulties. These include:

- With the pressure of commodity and market, businesses have to compete fiercely with others in order to survive. Therefore, business risk is high, and the risk of bankruptcy is even much higher.

- Competition for qualified workers is also one of the difficulties facing businesses.

- Poor quality products reduce the competitiveness of businesses in the market. Meanwhile, the domestic market is crowded out by foreign goods of good quality and design from China, Thailand etc.

- Constraints on access to capital for production and investment and tight production spaces.

- Some procedures and provisions on loans, production, and investment are cumbersome and complex.

\section{Regression Analysis on Vietnam SMEs' Participation in the Production Networks}

There are various theories explaining the participation of SMEs in production networks (Wignaraja 2012). One such explanation can be found in a new trade theory initiated by Melitz (2003). Melitz's seminal paper focuses on the heterogeneity of firms in international 
trade. Firms' decisions to export or not are influenced by two factors: firm productivity and sunk costs. Only highly efficient firms are able to export, invest in international market, and therefore participate in production networks, because they can overcome high entry costs, whereas less productive firms cannot and so have to concentrate on the domestic market.

The other explanation can be found in the fragmentation theory proposed by Jones and Kierzkowski (1990), which is applied popularly in rationalizing the formation of production networks. The theory emphasizes on the location of the production process, which is separated into several stages and located in different countries. There are three conditions affecting the feasibility of fragmentation. Firstly, firms can take advantage of dissimilarity in location, thereby saving production cost in fragmented production blocks. Secondly, service link costs that connect remotely located production blocks (e.g. costs of transportation, telecommunication, etc.) must be low. Finally, network set-up cost is low. A reduction in costs of these elements will improve the fragmentation of production networks. In the case of East Asian production/distribution networks, Kimura and Ando (2005) further develop fragmentation theory to cover the fragmentation by distance and fragmentation by firm disintegration (two-dimensional fragmentation).

According to Kimura and Ando (2005), fragmentation by distance raises the issues of higher transportation, telecommunication, distribution and coordination costs while possibly reducing production costs. Fragmentation by firm disintegration likely involves information costs as well as institution-related costs, but it might result in reduction of production costs due to more efficient supportive industries, availability of business partners, etc. In accordance with fragmentation theory, SMEs must overcome barriers related to types of fragmentation in order to participate in production networks.

To analyse the determinants of SME participation in the production networks of ASEAN countries, Harvie, Narjoko and Oum (2010) built a framework with external and internal factors on the basis of the empirical application of fragmentation theory. The statistical model used by Harvie, Narjoko and Oum (2010) is in the following form:

$$
P N_{i}=\gamma_{0}+\Gamma^{\prime} x_{i}+\varepsilon_{i}
$$


Where the equation is on the participation in the production networks, $i$ presents firm $i$ and $X_{i}$ is a vector of explainatory variables taking the SMEs' characteristics. The statistical model is a logistic one, that is used to overcome the fact that $\mathrm{PNi}$ is a $(0,1)$ variable reflecting the probability to participate in the production networks by SMEs.

Based on the results of the survey on the three manufacturing sectors, this study analyses further the determinants of the SMEs' participation in the regional production networks following the Harvie, Narjoko and Oum (2010) approach. The analysis is applied to the dependent variable of participation in production networks. With regards to the current database, the participating enterprises are mainly defined as those that export some of their products or import inputs for their production. Independent variables include firm size, age of firms, foreign ownership, labour productivity, skill intensity, industry variables and dummy variables regarding innovation activities, association membership and risk preference of firm managers.

In this analysis, age of firms is the number of years since the establishment of firms. Firm size is provided by the number of employees in the firms, foreign ownership stands for the control of foreign investors in the enterprises and measured by the share of foreign ownership. Labour productivity is measured by revenue per employee, while skill intensity is the share of employees with higher education in the total labour of firms.

Tables 9.17 and 9.18 show the differences in variables between enterprises of the three manufacturing sectors participating in production networks and those not in the networks. Table 9.17 indicates that SMEs that participate in production networks are significantly different from SMEs that do not participate in production networks in terms of size, foreign ownership, labour productivity and skill intensity. However, the two groups of SMEs do not differ in terms of operating years and training expenditure.

Two surprising facts include productivity and foreign ownership. These are puzzling since it is expected that foreign invested firms are more likely to join production networks, taking advantage of their relationship with the outside world. Also, productivity is usually assumed to be the most important characteristic that separate production network-participating firms from non-participating firms. Theories on production network participation emphasize the barriers to participate in production networks by SMEs and argue that productivity is one factor that helps SMEs to overcome these barriers. 
TABLE 9.17

Average Value of SME Characteristics

\begin{tabular}{lccc}
\hline & $\begin{array}{c}\text { SMEs in } \\
\text { Production } \\
\text { Network }\end{array}$ & $\begin{array}{c}\text { SMEs Not in } \\
\text { Production } \\
\text { Network }\end{array}$ & $\begin{array}{c}\text { Statistically } \\
\text { Different }\end{array}$ \\
\hline Age (years) & 8.3 & 9.1 & No \\
Size (employees) & 72.1 & 44.2 & Yes $^{* * *}$ \\
Foreign ownership (\%) & 9.9 & 1.0 & Yes $^{\star * *}$ \\
Labour productivity & 944.8 & 491.6 & Yes $^{* *}$ \\
(revenue/employee) & 38.9 & 27.7 & Yes $^{* * *}$ \\
Skill intensity (\%) & 33.4 & 23.2 & No \\
Training expense & & & \\
\hline
\end{tabular}

Notes: ${ }^{*} \mathrm{p}<0.10 ;{ }^{* *} \mathrm{p}<0.05 ;{ }^{* * *} \mathrm{p}<0.010$

TABLE 9.18

Comparison Between Participating and Non-participating Enterprises

\begin{tabular}{lccc}
\hline & $\begin{array}{c}\text { SMEs in } \\
\text { Production } \\
\text { Network }\end{array}$ & $\begin{array}{c}\text { SMEs Not in } \\
\text { Production } \\
\text { Network }\end{array}$ & $\begin{array}{c}\text { Statistically } \\
\text { Different }\end{array}$ \\
\hline $\begin{array}{l}\text { Having new/improved products/ } \\
\text { services }\end{array}$ & 56.6 & 45.4 & No \\
$\begin{array}{l}\text { Having new/improved methods } \\
\text { Having new/improved logistics/ } \\
\text { delivery }\end{array}$ & 59.4 & 48.5 & No \\
$\begin{array}{l}\text { Having new/improved } \\
\text { supporting activities } \\
\text { Belonging to industry/business }\end{array}$ & 33.0 & 27.8 & No \\
$\begin{array}{l}\text { associations } \\
\text { Having risk preference }\end{array}$ & 38.7 & 35.1 & No \\
\hline
\end{tabular}

Notes: ${ }^{*} p<0.10 ;{ }^{* *} p<0.05 ;{ }^{* * *} p<0.010$

Statistical tests on other dummy variables show that the two groups of SMEs in consideration are not different in several variables standing for innovations of SMEs. Also these two groups do not differ from each other in the risk preference of managers. However, the two groups are different in business association membership. The test shows that SMEs that participate in production networks tend to belong to 
business associations more often than those that do not participate in production networks (see Table 9.18).

Table 9.19 presents the estimation results of the logistic regression for the sample of all SMEs with less than 300 employees. This table reports eight specifications with specifications (1) and (2) as the baseline. They include all variables except dummy variables for innovations, business association membership and risk preference. Specification (2) is different from specification (1) with the dummy variables for the sectors of enterprises.

Among the main characteristics of enterprises, age has a negative impact on the probability of production network participation. With the exception of specification (3), age of enterprises has significantly and negatively influenced production network participation. This fact implicates that younger enterprises tend to be more active in participating in production networks. The regression results suggest that firm size is an important factor in determining the participation of enterprises in production networks.

The results also imply that foreign ownership and productivity are two other important determinants of participation of enterprises in production networks. The foreign ownership coefficients as estimated significantly determine the participation of SMEs in production networks. This fact is in accordance with the hypothesis on the advantages of enterprises that have connections with foreign markets in their ownership. The magnitude of foreign ownership effects as estimated is large in all specifications. The estimated marginal effects for these coefficients ranged from 0.56 to 0.67 percentage points. They are as large as the marginal effects of firm size on the participation of SMEs in production networks. However, their statistical significance is not as high as those of firm size, fluctuating between 5 per cent and 10 per cent significant levels.

The estimated coefficients of labour productivity are statistically significant and positive across the eight specifications. They are mostly significant at the 10 per cent level. The magnitude of the marginal effects of labour productivity is, however, very small, ranging from 0.0095 to 0.011 percentage points. These results imply that labour productivity is still a determinant of the participation of SMEs in production networks but with very limited impact.

The other two characteristics of SMEs in the three manufacturing sectors that are not statistically significant determinants of production 


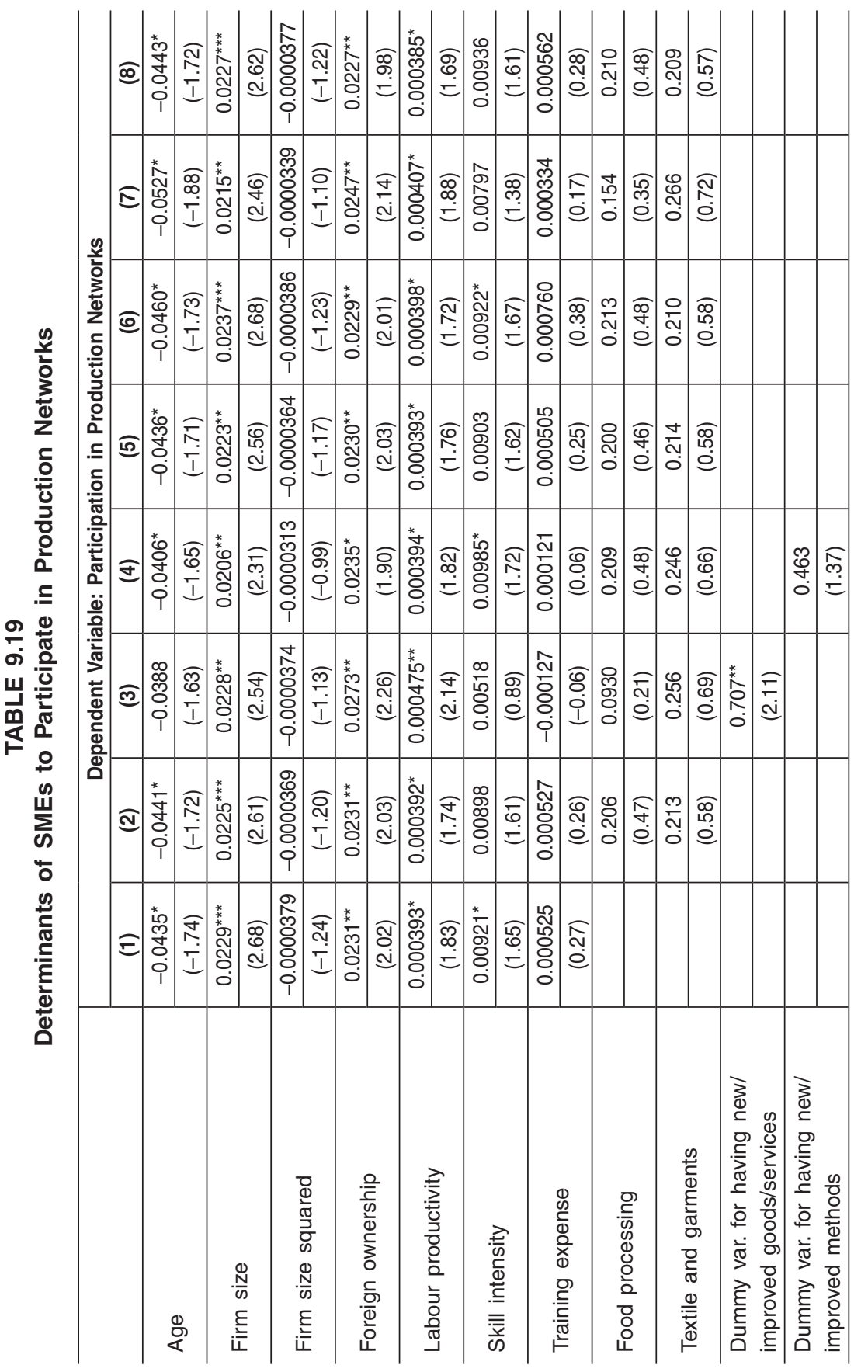




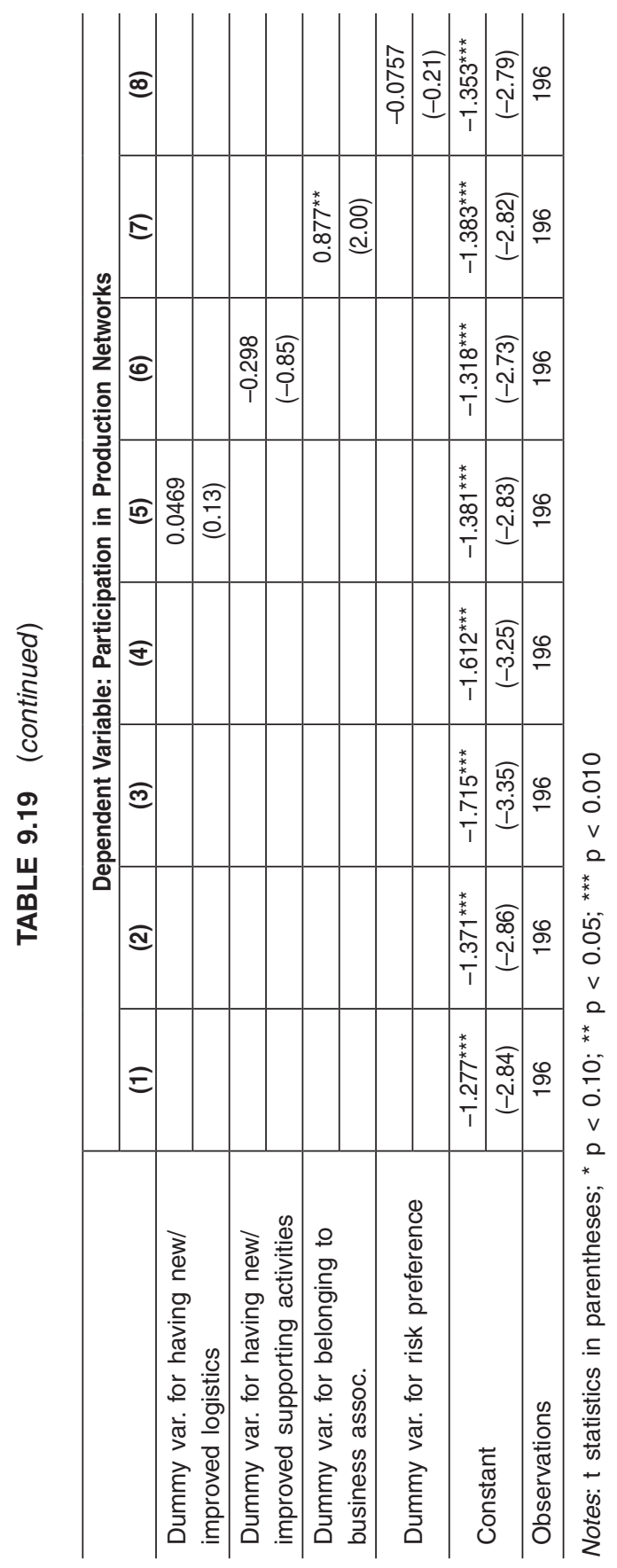


network participation are skill intensity and training expenses. The estimated coefficients are positive for both variables, but not stable for skill intensity and not significant for training expenses.

Among the behavioural activities of SMEs in terms of innovation, the regression analysis shows that creating new products/services and membership of industry and business associations are statistically significant and have positive impacts on the participation of SMEs in production networks. The general finding from the regression analysis is that connections in the form of foreign investment or membership of industry and business associations are important determinants of production network participation of SMEs. The analysis also shows that domestic connection, i.e. membership of industry and business associations, has far more significant impacts on the decision to participate in production networks by SMEs. The estimated marginal effect of industry and business association membership is 20 percentage points, compared to 0.6 percentage points of marginal effect of foreign ownership variable. In the same manner, magnitude of product innovation of SMEs is far larger than other variables, reaching 17 percentage points of marginal effect.

\section{Conclusions and Policy Recommendations}

Similar to the structure of the economy, the results of the survey show that the surveyed firms are mostly micro, small and mediumsized enterprises. In terms of establishment, the most common type is limited liability companies. These companies are mainly run as family businesses, of which 94 per cent are managed by the founders.

This fact can also partly explain the limited participation in the regional production networks by Vietnamese SMEs. Vietnam SMEs' participation in regional production is limited with only 15.4 per cent of enterprises having business relations with firms in other ASEAN countries. The awareness of Vietnam's enterprises on ASEAN SMEs Development Plan is relative high (66.7 per cent), but can be improved.

In terms of the perception of the influences of the AEC, the surveyed enterprises believe in an increase in domestic revenue, export sales, profits, market competitiveness and access to intermediate outputs. Particularly, 45.2 per cent of the enterprises stated that their domestic revenue increased, 66.7 per cent said that their export sales went up, 
73.8 per cent answered that their profits rosed, 69 per cent stated that their competitiveness in the domestic market increased, and 61.9 per cent confirmed that their competitiveness in international market increased. Meanwhile, another benefit of the AEC is lowering import expenses. About 59.5 per cent of total enterprises stated that AEC reduced their import costs. The AEC, therefore, has many influences as perceived by the surveyed Vietnamese enterprises in the three sectors.

In contrast with AEC, awareness of FTAs among Vietnamese SMEs is limited. Less than half of the surveyed firms (42.3 per cent) are aware of FTAs. It is surprising that only 25 per cent of large firms are aware of FTAs. The type of enterprises that is most aware of FTAs is the medium enterprises with 50.7 per cent of them being aware of the FTAs between Vietnam and other countries. The use of FTAs is also very limited. Among the 88 enterprises which are aware of FTAs, only 14 of them, or 15.9 per cent, are FTA users.

Among the FTAs non-users who are aware of the trade agreements, three reasons that are most often cited for not using FTAs are: (i) small trade volume with other countries, (ii) lack of knowledge, and (iii) other reasons.

Our regression analysis also shows that among the important determinants of production network participation, foreign ownership and productivity are two other important determinants of participation of enterprises in production networks. Among the behavioural activities of SMEs in terms of innovation, the regression analysis shows that creating new products/services and membership of industry and business associations are statistically significant and have positive impacts on the participation of SMEs in production networks. The general finding from the regression analysis is that connections in the form of foreign investment or membership of industry and business associations are important determinants of production network participation of SMEs. The analysis also shows that domestic connection, i.e. membership of industry and business associations, has far more significant impacts on the decision to participate in production networks by SMEs.

The analysis implies some policy recommendations to enhance the participation of Vietnamese SMEs in regional production networks. Participating in production networks and development of SMEs is 
a two-way relationship. Policies to develop SMEs will certainly help to improve SME participation in regional production networks. Also, policies to promote labour productivity have the same implications. Policies to continue the international integration are proven to help SMEs involve in production networks by promoting foreign ownership.

From the enterprise perspective, new or significantly improved products or services and industry/business association membership will help to promote SME participation in production networks. Therefore, government policies to promote product innovation as well as expansion of industry and business associations are believed to be helpful. Also information on ASEAN SMEs' policies, AEC and other business related issues should be promoted to enterprises to raise their awareness. These will help to significantly improve the participation of Vietnam SMEs in regional production networks.

\section{NOTES}

1. An estimation by the World Bank shows that each job created by Vietnamese SMEs requires an investment of about US $\$ 800$. Meanwhile, a state-owned enterprise (SOE) requires US\$18,000 to create a new job.

2. Section 3 of the Small Business Act of 1953.

3. This census surveyed all business establishments (administrative and nonprofit) in the country.

4. A comprehensive description of these support programmes can be found in the report by AED (2014).

5. Source: <http:// smartex.com.vn/vi/thong-tin-thi-truong/nghien-cuu-thitruong/nganh-hang-n33.5oi-bat/ thong-tin-thi-truong-the-gioi/ may-mac-vadet-may / 48-nganh-det-may-viet-nam>.

6. General Statistics Office, Vietnam's export and import of commodities in 2011.

7. General Statistics Office, Vietnam's export and import of commodities in 2012.

8. General Statistics Office, Vietnam's export and import of commodities in 2013.

9. CTCK Rồng Việt, "Dệt may 2015 dự báo tiếp tục tăng trưởng tốt" [Textile and Apparel 2015 Forecast Continued Good Growth], 4 April 2015, available at <http: / / tinnhanhchungkhoan.vn/ thuong-truong/ det-may-2015-du-baotiep-tuc-tang-truong-tot-115828.html>. 
10. VŨ Phong, "Dệt may cần ODM" [Textile Needs ODM], 8 July 2014, available at <http://nld.com.vn/ kinh-te/ det-may-can-odm-20140708180853189. htm $>$.

11. Thu Hiền, "Dệt may Việt Nam hưởng tới vị trí thứ 3 thế giới về xuất khấu năm 2015" [Vietnam's Textile and Garment Industry is Aiming for the Third Position of Top Exporters in World Exports in 2015], available at <http: / / www.agtex.com.vn/ zone/ det-may-viet-nam-huong-toi-vi-tri-thu3-the-gioi-ve-xuat-khau-nam-2015/258/424>.

12. Nguyễn Tấn Dũng, "Ngành Dệt may: Cả thế giới chọn Việt Nam là đối tưởng cạnh tranh" [Textile and Clothing: The Whole World Chooses Vietnam as a Competitive Destination], 16 January 2015, available at <http:// nguyentandung.org/nganh-det-may-ca-the-gioi-chon-viet-nam-la-doi-tuongcanh-tranh.html>.

13. "Textile 2015: Welcome to New Chance", Vietnam Trade and Industry Review, available at <http: / / congthuongthainguyen.gov.vn/gpmaster.gp-media. so-cong-thuong-thai-nguyen.gplist.234.gpopen.4153.gpside.1.det-may-2015chuan-bi-don-co-hoi-moi.asm $x>$.

14. "Dữ liệu mới nhất về ngành dệt may ghi nhận cả tiến bộ và thách thức về bình đẳng giới" [The Latest Data on the Textile Industry Notes Both Progress and Challenges in Gender Inequality], 7 March 2015, available at <http:/ / www.ilo.org/hanoi/Informationresources/Publicinformation/ Pressreleases/WCMS_349654/lang--vi/index.htm>.

15. CTCK Rồng Việt, "Dệt may 2015 dự báo tiếp tục tăng trưởng tốt" [Textile and Apparel 2015 Forecast Continued Good Growth], op. cit.

16. Lien Hoa, "Liên kết các doanh nghiệp dệt may Việt Nam đế tăng lợi thế cạnh tranh" [Link Vietnam's Garment Enterprises to Increase Competitive Advantage], 24 March 2015, available at <http:/ / www.phongphucorp.com/ news/lien-ket-cac-doanh-nghiep-det-may-viet-nam-de-tang-loi-the-canh-tranhvi.html>.

17. Vietnam Economic Growth Report 2015, available at <http://vef.vn/201504-16-bao-cao-tang-truong-viet-nam-nam-2015>.

18. Luu Yen, "Công nghe thuc pham: Đón đau su phát trien", huongnghiep24h, available at $<$ http:/ / huongnghiep24h.com/tu-van-nghe-nghiep/ cong-nghethuc-pham-don-dau-su-phat-trien.html>.

19. Hai Phan, "Ngành thuc pham - đo uong: Toa sáng tu canh tranh" [Food Industry: Shining from the Competition], Vietnamnet.vn, 3 January 2014, available at <http:/ / vietnamnet.vn/vn/ kinh-te/156350/nganqh-thuc-pham--do-uong--toa--sa-ng-tu-canh-tranh.html>.

20. "Mapping the Stakeholders for FLEGT VPA in Vietnam", Forest Trend $11 / 2011$. 


\section{REFERENCES}

Agency of Enterprise Development (AED). Guidance on SMEs Support Programs (Vietnamese). 2014.

Al-Qirim, Nabeel. Electronic Commerce in Small to Medium-Sized Enterprises: Frameworks, Issues and Implications. U.S. and UK: Idea Group Publishing, 2004.

Chau, Stephen B. and Paul Turner. "An SME Experience of E-Commerce: Some Considerations for Policy Formulation in Australia". In e-Business, e-Government and Small and Medium-Size Enterprises: Opportunities and Challenges, by Brian J. Corbitt and Nabeel Al-Qirim. U.S. and UK: Idea Group Publishing, 2004.

Deloitte. Connected Small Businesses: How Australian Small Businesses are Growing in the Digital Economy. 2013. Available at <https://www2.deloitte.com/ content/ dam / Deloitte / au / Documents / Economics / deloitte-au-economicsconnected-small-businesses-google-100413.pdf $>$.

Devos, Jan, Hendrik van Landeghem, and Dirk Deschoolmeester, eds. Information Systems for Small and Medium-Sized: State of Art of IS Research in SMEs. Berlin: Springer, 2014.

Dinh, Hinh T., Deepak Mishra, Le Duy Binh, Duc Minh Pham, and Pham Thi Thu Hang. Light Manufacturing in Vietnam: Creating Jobs and Prosperity in a Middle-Income Economy. Washington, D.C.: World Bank, 2013.

Forest Trend. "Mapping the Stakeholders for FLEGT VPA in Vietnam". Report, 2011.

Jones, Robert W. and Henryk Kierzkowski. "The Role of Services in Production and International Trade: A Theoretical Framework". In The Political Economy of International Trade: Essays in Honour of Robert E. Baldwin, edited by Ronald W. Jones and Anne O. Krueger. Oxford, UK: Basil Blackwell, 1990, pp. 31-48.

Harvie, Charles. "SMEs and Regional Production Networks". In Integrating Small and Medium Enterprises (SMEs) into the More Integrated East Asia, edited by Vo Tri Thanh, Dionisius Narjoko, and Sothea Oum. Jakarta: Economic Research Institute for ASEAN and East Asia (ERIA), 2010, pp. 19-45.

Harvie, Charles and Boon-Chye Lee. Sustaining Growth and Performance in East Asia: The Role of Small and Medium Sized Enterprises. Cheltenham, UK: Edward Elgar, 2005.

Harvie, Charles, Dionisius Narjoko, and Sothea Oum. "Firm Characteristic Determinants of SME Participation in Production Networks". ERIA Discussion Paper Series, ERIA-DP-2010-11. October 2010.

Kimura, Fukunari and Mitsuyo Ando. "Two-dimensional Fragmentation in East Asia: Conceptual Framework and Empirics". International Review of Economics and Finance 14, no. 3 (2005): 317-48. 
MacGregor, Robert and Lejla Vrazalic. E-Commerce in Regional Small to Medium Enterprises. New York: IGI Publishing, 2007.

Melitz, Marc J. “The Impact of Trade on Intra-Industry Reallocations and Aggregate Industry Productivity". Econometrica 17, no. 6 (2003): 1695-1725. Ministry of Agriculture and Rural Development (MARD). "Development Planning of the Wood Processing Industry". Report, 2013.

Tambunan, Tulus. SMEs in Asian Developing Countries. UK: Palgrave Macmillan, 2009.

Trang, N.T.T.T. and P.M. Thuy. Supporting Business Association to Implement the Development Strategy of Wood Processing Industry (Vietnamese). 2014.

Wignaraja, Ganeshan. "Engaging Small and Medium Enterprises in Production Networks: Firm- level Analysis of Five ASEAN Economies". ADBI Working Paper 361. Tokyo: Asian Development Bank Institute, June 2012. 